\title{
Eighteen-carbon trans fatty acids and inflammation in the context of atherosclerosis
}

\author{
Carina A. Valenzuela ${ }^{a, b}$, Ella J. Baker ${ }^{a}$, Elizabeth A. Miles ${ }^{a}$ and Philip C. Calder ${ }^{a, c}$
}

aschool of Human Development and Health, Faculty of Medicine, University of Southampton, Southampton SO16 6YD, United Kingdom;

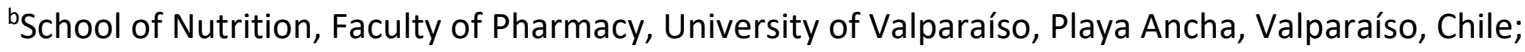
'NIHR Southampton Biomedical Research Centre, University Hospital Southampton NHS Foundation Trust and University of Southampton, Southampton SO16 6YD, United Kingdom

Author for correspondence: Philip Calder, School of Human Development and Health, Faculty of Medicine, University of Southampton, IDS Building, MP887 Southampton General Hospital, Tremona Road, Southampton SO16 6YD, United Kingdom; email: P.C.Calder@soton.ac.uk

Key words: Trans fatty acid; Inflammation; Atherosclerosis; Cytokines; Endothelium; Conjugated linoleic acid.

\section{Abbreviations used:}

$\mathrm{BMI}$, body mass index;

$\mathrm{CHD}$, coronary heart disease;

CLA, conjugated linoleic acid;

CLA9,11, cis-9, trans-11 CLA;

CLA10,12, trans-10, cis-12 CLA;

CRP, C-reactive protein;

CVD, cardiovascular disease;

DHA, docosahexaenoic acid;

$E A$, elaidic acid;

EPA, eicosapentaenoic acid;

FA, fatty acid;

HAECs, human aortic endothelial cells;

HCASMCs, human coronary arterial smooth muscle cells;

HDL, high density lipoprotein;

HMECs, human microvascular endothelial cells;

HUVECs, human umbilical vein endothelial cells;

ICAM-1, intercellular adhesion molecule-1;

IFN, interferon;

IK $\beta$, inhibitor of NFK $\beta$

IL, interleukin;

iTFA, industrial trans fatty acid;

LDL, low density lipoprotein;

LPS, lipopolysaccharide;

MCP-1, monocyte chemoattractant protein 1;

mRNA, messenger RNA;

NAFLD, non-alcoholic fatty liver disease;

$\mathrm{NF}-\mathrm{k} \beta$, nuclear factor kappa-beta;

PAI-1, plasminogen activator inhibitor-1;

PBMC, peripheral blood mononuclear cell;

PHSO, partially hydrogenated soybean oil;

PHVF, partially hydrogenated vegetable fat;

PPAR, peroxisome proliferator activated receptor;

PUFA, polyunsaturated fatty acid;

rTFA, ruminant trans fatty acid; 
SOD-2, superoxide dismutase 2;

TAG, triacylglycerol;

TFA, trans fatty acid;

$T L R$, toll-like receptor;

TNF- $\alpha$, tumour necrosis factor alpha;

TNF-RI, tumour necrosis factor receptor 1 ;

TVA, trans-vaccenic acid;

VCAM-1, vascular cell adhesion molecule-1; 
Abstract

Endothelial dysfunction is a pro-inflammatory state characterized by chronic activation of the endothelium, which leads to atherosclerosis and cardiovascular disease (CVD). Intake of trans fatty acids (TFAs) is associated with an increased risk of CVD. This risk is usually associated with industrial TFAs (iTFAs) rather than ruminant TFAs (rTFAs); however it is not clear how specific TFA isomers differ in their biological activity and mechanisms of action with regard to inflammation. Here we review the literature on 18-carbon TFAs, including the research associating their intake or levels with CVD and studies relating 18-carbon TFA exposure to modulation of inflammatory processes. The evidence associating iTFAs with CVD risk factors is fairly consistent and studies in humans usually show a relation between iTFAs and higher levels of inflammatory markers. In contrast, studies in humans, animals and in vitro suggest that rTFAs have null or mildly beneficial effects in cardiovascular health, metabolic parameters and inflammatory markers, although the evidence is not always consistent. More studies are needed to better identify the beneficial and detrimental effects of the different TFAs, including those with 18 carbons. 


\section{Introduction}

Inflammation is an essential component of innate immunity, helping to defend the host against infections. The initial acute phase of the inflammatory response is followed by resolution and recovery, with activation of negative feedback mechanisms that oppose the inflammatory signals, remove damaged cells and tissue debris, and promote the repair of damaged tissues. In many chronic illnesses, the self-limiting nature of inflammation is lost, contributing to the pathology of the disease due to on-going (i.e. chronic) inflammation [1, 2]. This has been described for many highly prevalent conditions such as obesity, coronary heart disease (CHD), non-alcoholic fatty acid liver disease (NAFLD) and type 2 diabetes [3, 4].

Fatty acids (FAs) are key components of cell membrane phospholipids, through which they are able to modify cell responses to inflammatory signals. Among FAs, trans fatty acids (TFAs) are unsaturated FAs containing one or more double bonds in the trans rather than the cis geometric configuration. Since humans cannot produce TFAs de novo, plasma and tissue levels of TFAs reflect dietary intake. Dietary TFAs can have two origins, being produced either through metabolism in a living organism or through industrial or processing manipulations of fats and oils. The main source of TFAs in western diets is partially hydrogenated vegetable oils, which have been extensively associated with adverse health outcomes, particularly, increasing risk factors for cardiovascular disease (CVD) and systemic inflammation. A high intake of partially hydrogenated vegetable oil TFAs has been shown to induce an altered blood lipid profile, with increased levels of triacylglycerols (TAGs) and low density lipoprotein (LDL)-cholesterol and decreased levels of high density lipoprotein (HDL)-cholesterol, together with a pro-inflammatory state and endothelial dysfunction [5, 6]. A second type of dietary TFAs are the ones produced naturally via biohydrogenation of unsaturated fats by ruminant bacteria. There remains debate regarding the health effects of ruminant fat intake; however, growing evidence suggests that the major ruminant TFAs (rTFAs) are neutral or even beneficial for health. Most prospective studies show that diets enriched in rTFAs have no significant effects on plasma C-reactive protein (CRP) levels or blood lipids, while decreasing plasma levels of cytokines like interleukin (IL)-6, IL-8 and tumour necrosis factor (TNF)- $\alpha$ [7-9].

CHD and stroke have remained the leading causes of death globally in the last 15 years [10]; therefore, decreasing the risk for these CVDs by reducing the intake of harmful TFAs continues to be a major public health objective worldwide. Even before the World Health Organisation announcement in 2018 recommending the elimination of industrially produced TFAs from the food supply [11], many countries had adopted TFA regulations, including the European Union [12-14]. 
Nevertheless, more than 110 countries have not yet established regulations against TFAs, meaning that 5 billion people are still at risk from iTFA exposure (World Health Organisation, 2019). However, it is not clear how specific TFA isomers differ in their biological activity and mechanisms of action with regard to inflammation. Considering the need for greater knowledge about the possible differential effects of TFAs on inflammation, the aim of this article is to review the current evidence in this matter. A previous review described the broad-ranging effects of conjugated linoleic acids (CLAs) and their mechanisms of action [15]. There have been a number of studies of CLAs published since that review. In addition, the current review also considers common trans monounsaturated fatty acids and focusses upon inflammation in the context of atherosclerosis.

\section{TFA structure and metabolism}

TFAs from natural and industrial sources have different structures; the main 18-carbon TFAs that have been studied are shown in Table 1. Ruminant biohydrogenation of unsaturated FAs produces mainly trans-vaccenic acid (TVA; trans-11 18:1) and cis-9, trans-11 conjugated linoleic acid (CLA9,11) as intermediates during bacterial fermentation. In contrast, during catalytic hydrogenation of vegetable oils, TAG ethylenic double bonds progressively disappear by being saturated by hydrogen. Before disappearing, their positions can shift along the FA chain (positional isomerization) and/or their geometry can change from cis to trans configuration and back, leading to various TFAs in the final product, although the main one is elaidic acid (EA; trans-9 18:1).

In a trans double bond, the two hydrogen atoms bound to the carbon atoms that form the double bond are located on opposite sides of the carbon chain. Unlike the cis isomeric configuration, the double bond angle of TFAs is smaller and the acyl chain is more linear, resulting in a more rigid and straight molecule with a higher melting point. The spatial structure of TFAs is between that of saturated FAs and cis unsaturated FAs [16]. Consequently, the presence of trans double bonds causes the physical properties of the FA to be more similar to those of a saturated rather than an unsaturated FA. As with cis FAs, TFAs can be metabolized by oxidation, elongation, and desaturation processes [17]. There is evidence that TVA can be converted into CLA9,11 in different human, mouse

and ruminant tissues (e.g. adipose tissue, mammary glands) [18-22], while the metabolism of EA has been related to an increase in 18:3 TFAs [23], and other unknown FAs. CLAs can also be desaturated and elongated to conjugated $18: 3,20: 3$ and $20: 4$ isomers [24-26].

TFAs can also be stored in adipose tissue and incorporated into membrane lipids, which would make the membranes less fluid and may influence membrane protein function and interactions and lipid raft formation, in turn affecting cell signalling processes [27]. 


\section{Sources, intake and recommendations for TFAs}

As indicated earlier, there are two main sources of TFAs in the diet. Quantitatively the main source of TFAs is usually partially hydrogenated vegetable oils; the process of hydrogenation is used to convert liquid oils into solid or semisolid fats, for example to produce margarine [28]. The development of the hydrogenation process in the early 20th century led to the introduction of significant amounts of these iTFAs into the Western diet. During the course of the 20th century, the production of partially hydrogenated vegetable oils increased steadily because of their low cost, long shelf life, and suitability for commercial frying [29]. The intermediate melting point of iTFAs provides favourable characteristics to food, such as texture and palatability, and greater stability [30]. Additionally, their use was extended during the last part of 20th century as food manufacturers needed a replacement to butter due to health recommendations to reduce saturated fat and cholesterol intake [31]. EA is the most predominant iTFA. Oleic acid (cis-9 18:1 or 18:1n-9) is the most common monounsaturated fatty acid found in many vegetable oils. When exposed to partial hydrogenation, oleic acid changes its configuration and becomes EA. While EA is the prime form of iTFA, other fatty acids in trans form can also be found in processed food products (i.e. trans isomers of $18: 2,18: 3$ and 16:2) [30]. Some of the commonly eaten foods with a high amount of iTFAs are fried foods, fast foods, pastries, margarines, shortenings, cake mixes and many frozen meals and packaged foods [30]. Another way to contribute TFAs to the diet is through cooking processes, such as high temperature frying of vegetable oils as in fried processed and fast food [32]. Trace amounts of TFAs are also produced during the process used to deodorize or refine vegetable oils [33].

The second main source of TFAs is the naturally occurring TFAs formed by bacterial isomerases capable of converting the double bonds of polyunsaturated fats in plants to a trans configuration in the stomachs of ruminant animals. These rTFAs are found in grass grazing sheep and cattle. Therefore, meats of these animals as well as milk and milk products (cheese and butter) contain rTFAs [30]. TFAs in ruminant milk and meats represent about $2 \%$ to $6 \%$ of the total fat content [34]. The major contributor within this kind of TFA is TVA, which constitutes $50-80 \%$ of all rTFAs [35]. CLAs are also found in ruminant products and are identified by two double bonds within the aliphatic chain separated by a single bond in between [30]. Rumenic acid (cis-9, trans-11 CLA; CLA9,11) accounts for $70-80 \%$ of the total CLA content in dairy and meat products. The amount of trans-10, cis-12 CLA (CLA10,12) is less than $5 \%$ of total CLA and less than $0.1 \%$ of total fat content [36]. It is estimated that in North America $10-25 \%$ of total TFAs consumed are from ruminant sources [37-39] , although this could be higher in some countries in Europe, like Denmark or Germany [36]. 
It seems that the greatest contributor of TFAs in the Western diet is processed food products due to the high concentration of TFAs in partially hydrogenated vegetable oils, as high as 30 to $50 \%$, compared to only $5-6 \%$ in dairy and ruminant meat products [40].

The National Diet and Nutrition Survey performed in 2008-2009 in the United Kingdom showed an intake of less than $2 \mathrm{~g} /$ day of TFAs for all age groups ( $0.8 \%$ of daily energy intake for adults), reporting a decreased intake compared to the past surveys of 1997 and 2000 [41]. However, this survey did not assess the intake from takeaway food from independent outlets, and so might have underestimated TFA intake. The Framingham Offspring cohort, which consists of older, predominately white, American adults, also reported a decreased intake of TFAs over time (1991 1998), from $1.6 \%$ to $1.2 \%$ of daily energy intake, probably due to a reduction in margarine consumption [42].

Regarding the intake of natural TFAs, Hulshof and colleagues described an intake $<2 \mathrm{~g} /$ day of rTFAs in all Western European countries in the TRANSFAIR study, also reporting that the main contribution of TFAs in the diet was from industrial sources [43].

In the 1990s, the iTFA intake reported in the US population was between 5 and $10 \mathrm{~g} /$ day, with an upper limit of $20 \mathrm{~g} /$ day, and that corresponded to approximately $2-5 \%$ of total energy in the diet $[37,44]$. More recently, a decreased intake of iTFAs in the USA has been reported: going from 4.6 $\mathrm{g} /$ day in 2003 to $1.3 \mathrm{~g} /$ day in 2010, as a result of legislation and food labelling [45]. Nevertheless, there are people who still show high intakes of iTFAs due to high consumption of processed and fast food, ranging from 3.5 to $12.5 \%$ of daily energy intake [46].

Data on TFA intake usually rely on estimates of food consumption and the use of appropriate food composition tables. The estimates of food consumption need to be detailed given that the content of iTFAs in apparently similar foods may vary considerably in the same country and from time to time, depending on market prices of fats, and on the disposition of the food industry to reduce the content of iTFAs in their products. On the other hand, concentrations of rTFAs in ruminant products also vary in relation to the food given to animals and therefore with the seasons [47]. However, this variation in gram per serving is much lower than the variation observed for iTFAs. As a consequence, TFA intake estimations should be interpreted with caution and preferably be supported by analysis of food portions and measurements of biomarkers for intake, such as TFAs in human plasma or tissues like erythrocytes, subcutaneous fat, and human milk [48].

Another problem with estimating the amount of dietary TFAs consumed occurs because of the differences in food labelling legislation between countries. For example, the presence of small 
amounts of TFAs in oils and hydrogenated or partially hydrogenated food products could generate an intake above the recommended limits and this could be exacerbated by labelling rules. In the USA, the Food and Drug Administration allows products containing $<0.5 \mathrm{~g}$ of trans fat per serving to indicate a contribution of $0 \mathrm{~g}$ of trans fat. If a person consumes several products that contribute almost $0.5 \mathrm{~g}$ of trans fats per serving during the day, they could easily exceed the recommendation of less than $1 \%$ of daily energy intake (approximately $2 \mathrm{~g}$ of TFAs in a $2000 \mathrm{Kcal} /$ day based diet), while labels indicate that they are free of trans fats [49].

Until recently the European Union did not have legislation regulating the content of trans fats in food products or specific requirements about their labelling. In April 2019, the European Commission decided to limit the amount of iTFA in food products to $2 \mathrm{~g}$ per $100 \mathrm{~g}$ of fat. The deadline to comply with the European regulation is $1^{\text {st }}$ April 2021, after which products with higher amounts of iTFA will not be allowed to be placed on market [50]. It is still unclear if the exact amount of iTFAs will be required to be included in the nutrition label of pre-packed products. Meanwhile, several European countries have made voluntary agreements with the food industry to reduce the amount of TFAs in foods; the United Kingdom is one of them.

Due to the overall negative effects of TFAs on health, it is currently recommended that these fatty acids contribute $<1 \%$ of daily energy intake; in fact their poor health associations suggest that TFA intake should be as low as possible [51-54]. It is important to note that these recommendations do not distinguish by type of TFA (ruminant versus industrial), when there is evidence that the health effects of each type could be different (see later sections).

\section{Concentrations of 18-carbon TFAs in human blood, cells and tissues including changes over time and response to increased intake}

\subsection{Concentrations of 18-carbon TFAs in humans}

The observational studies that first described the health risks associated with TFAs measured consumption through food intake surveys, mainly focused on partially hydrogenated vegetable oils, but there are many problems with establishing TFA intake accurately, as described in the previous section. Instead, TFA levels in tissues or in plasma may be good biomarkers of dietary intake. Nevertheless, there are not many studies describing TFA levels in representative samples of populations in different health conditions, and because of that the interpretation of this data is difficult, with no reference values of normal or desirable TFA levels to compare [55]. 
Table 2 shows a summary of the studies published reporting absolute concentrations of plasma 18carbon TFAs in healthy subjects. The mean plasma concentration of EA, the main iTFA of the diet, was $32.5 \mu \mathrm{mol} / \mathrm{L}$ in young Canadian adults measured in 2010 [55] and $13.5 \mu \mathrm{mol} / \mathrm{L}$ in middle age adults from the USA, measured between 2009 and 2010 [56]. In contrast, the average levels of TVA were lower in young compared to the middle aged adults ( $9.41 \mathrm{vs} 18.2 \mu \mathrm{mol} / \mathrm{L}$, respectively), which reflects differences in food intake patterns, with a lower intake of dairy and higher intake of processed foods in the group of younger adults.

In relation to CLAs, both studies in Canadian young adults showed similar plasma levels, 14.4 vs 17.5 $\mu \mathrm{mol} / \mathrm{L}$ average for CLA9,11. For CLA10,12 the average was reported as 4.3 and $6.3 \mu \mathrm{mol} / \mathrm{L}$ in plasma, respectively. Another study measured total CLA level (i.e. 9c11t $+10 t 12 c$ ) in 750 middle age European adults, reporting circulating plasma phospholipid levels, with an average of $11.2 \pm 1.8$ $\mu \mathrm{mol} / \mathrm{L}[57]$.

As is common practice in the literature, TFA levels expressed as proportions of total FAs have been described in plasma lipids [55], different plasma lipid fractions [58, 59], erythrocytes [60-62], blood immune cells $[58,59]$, adipose tissue $[63-66]$, and breast milk $[67,68]$ in humans; these data are summarised in Table 3. It is clear that 18-carbon TFAs make a significant contribution (i.e. $>1 \%$ of total FAs) to blood lipids, blood cells and adipose tissue in humans. The contribution to the FA component of other tissues in humans is not known. However, given that the total number of FAs measured differ amongst studies, the comparison of \% values between different studies is challenging.

Studies that measure plasma and tissue levels of TFAs as absolute concentrations in healthy and non-healthy subjects are needed to establish reference values that allow to determine when reported levels are normal/safe or not, and to be able to associate TFA levels with their beneficial or detrimental effects in a better way.

\subsection{Changes in plasma 18-carbon TFA concentrations over time}

Decreased reported intakes of TFAs together with public and private efforts to reduce partially hydrogenated oils in food products in different countries, as described earlier, have led to decreased total and individual levels of TFAs measured in plasma over time in healthy subjects $[34,42,43,56]$. Despite this, there are still groups in the population with very high intakes of TFAs, which are reflected in the highest plasma TFA concentrations reported by Abdelmagid et al.: $88 \mu \mathrm{mol} / \mathrm{L}$ for EA, $74 \mu \mathrm{mol} / \mathrm{L}$ for TVA, $42 \mu \mathrm{mol} / \mathrm{L}$ for CLA9,11 and $18 \mu \mathrm{mol} / \mathrm{L}$ for CLA10,12 [69]. As shown in Figure 1, changes in plasma 18-carbon TFA concentrations over time are also isomer specific. This crosssectional cohort study shows a consistent decrease in plasma concentrations of most of the common 
18-carbon TFAs from 2004 to 2009, although EA increased back to the initial levels in 2010, suggesting that this group of young Canadian adults might be vulnerable to iTFA exposure. Monitoring food iTFA levels in vulnerable populations is still needed [55].

\subsection{Response of blood and cell 18-carbon TFAs to increased intake}

Although TFAs can be interconverted in humans through metabolic processes such as $\beta$-oxidation and elongation and desaturation pathways, they are not formed de novo in humans. Thus, concentrations in the blood, cells and tissues are likely to be highly related to dietary intake. This is clearly demonstrated in Figure 2 which relates adipose tissue CLA9,11 concentration (expressed as \% of total FAs) to dietary intake of CLA9,11 [64] The relationship between dietary exposure to TFAs and blood and cell levels is also clearly demonstrated in intervention studies which show that experimentally increased intake of various TFAs leads to higher levels of those TFAs in blood and blood cells. A study conducted in healthy men with near pure CLA9,11 and near pure CLA10,12 illustrates this very well [58, 60] (Figure 3). Healthy male volunteers aged 20-47 years (mean age 31 years; mean body mass index $24.5 \mathrm{~kg} / \mathrm{m}^{2}$ ) consumed either encapsulated CLA9,11 or CLA10,12 for three consecutive 8-week periods with increasing dose, before crossing over to the other isomer after a washout period. Subjects therefore consumed each isomer for 6 months, separated by a 6week washout period. The CLA isomers were provided in capsules, containing approximately 80$85 \%$ of either CLA9,11 or CLA10,12 in TAG form. Subjects consumed one, two or four capsules per day, which provided $0.59,1.19$ or $2.38 \mathrm{~g} /$ day CLA9,11 or $0.63,1.26$ or $2.52 \mathrm{~g} /$ day CLA10,12 CLA, respectively. Mean compliance assessed by capsule counting was $92 \%$, and was not different between doses or isomer treatment. Blood samples were collected at each visit after a fast of at least $10 \mathrm{~h}$. The results demonstrate a clear linear dose-response relationship between exogenous provision of CLA9,11 and CLA10,12 and the appearance of those two FAs in plasma lipids and in blood mononuclear cells [58] (Figure 3). The appearance of the two CLAs in erythrocytes is also likely to be a linear dose-response but the study did not report findings from the one and two capsules per day groups, only for the zero and four capsules per day groups [60] (Figure 3).

\section{Association of 18-carbon TFAs with CVD risk, morbidity and mortality}

Several studies have reported that intake of TFAs correlates to higher risk of CHD. A meta-analysis of prospective cohort studies by Mozaffarian and colleagues indicated that a $2 \%$ absolute increase in energy intake from TFAs, equivalent to $4 \mathrm{~g}$ daily in a $2,000 \mathrm{kcal}$ diet, was associated with a $23 \%$ increase in cardiovascular risk [70]. 
The Nurses' Health Study showed that those in the highest quintile of TFA intake had a relative risk of developing CHD 1.5 times greater when compared to those in the lowest quintile, after adjustment for age and total energy intake [71], and that higher risk was maintained over time [72, 73]. A nested case-control study in the same cohort was conducted using measurement of TFA levels in plasma and red blood cells, showing that higher total erythrocyte TFA content was associated with higher CHD risk, with a relative risk 3.3 times greater in the quartile with the highest TFA level compared to the lowest [74]. Regarding the type of TFA, in the first report from the Nurses' Health Study in 1993, TFA intake was partitioned into industrial and ruminant sources, and the positive association with CHD risk was entirely explained by iTFAs [71].

In the Boston Health Study, the intake of TFAs was directly related to the risk of myocardial infarction, with a relative risk of 2.44 in the cases compared to the controls, after adjustment for age, gender and total energy intake [75], and this risk was completely accounted for by iTFAs rather than rTFAs.

Another study in 21,930 Finnish men, showed that total TFA consumption was strongly correlated with intake of margarine but not with butter, and the estimated intake of iTFAs was positively associated with risk of CHD. In contrast, estimated intake of TFAs from ruminant sources was inversely associated to $\mathrm{CHD}$, with a relative risk of 0.83 for the highest compared to the lowest quintile of intake [76].

In the Danish Cohort studies, where 3,686 adults were followed for 18 years, no significant associations were found between rTFA intake and risk of CHD, but among women indications of inverse associations between the absolute rTFA intake and the risk of CHD were described [77].

One previous study, however, indicated a positive association between energy-adjusted rTFA intake and risk of CHD among men. Oomen and colleagues reported that for each $0.5 \%$ of energy, the fully adjusted relative risk of CHD for rTFAs, industrial 18:1 TFAs, and other industrial TFA intake was similar in the Dutch elderly men cohort [78].

In summary, the evidence from observational studies suggests that higher CHD risk is related to consumption of industrially produced TFAs rather than to rTFAs.

The cardiovascular risk associated with iTFAs can be explained, at least in part, by their effects on lipoproteins, such as LDL and HDL cholesterol, as well as on inflammatory mechanisms. The effects of TFA consumption that are consistently seen in both controlled trials and observational studies comprise adverse lipid effects, including increased fasting TAGs [79] and LDL cholesterol, decreased HDL cholesterol and an increased total/HDL cholesterol ratio $[74,79,80]$; pro-inflammatory effects, 
including higher TNF- $\alpha$ system activity (increased plasma concentrations of TNF- $\alpha$ and soluble TNF- $\alpha$ receptors), IL-6 levels and C reactive protein concentrations [81-85]; and endothelial dysfunction, assessed by both circulating and functional measures $[81,86,87]$. These effects were significant in comparison with cis unsaturated fats; the adverse effects of TFAs on the total to HDL cholesterol ratio and on endothelial function have also been reported when comparing with saturated fatty acids.

\section{Role of inflammation in CVD}

Inflammation is a component of innate immunity, and it is part of the body's response to injury or infection. The response includes an increase in blood flow, capillary dilatation, leukocyte infiltration and the localised production of chemical mediators. Crucial early steps in the inflammatory response are an increased supply of blood to the site of inflammation and an increase in vascular wall permeability that allows large molecules and cells (leukocytes, or white blood cells) to cross the endothelium. These newly arrived and activated leukocytes then release chemical mediators at the site of inflammation. Increased mediators include adhesion molecules (intercellular adhesion molecule 1, ICAM-1), vascular cell adhesion molecule 1 (VCAM-1) and E-selectin on the surface of endothelial cells, causing the binding and diapedesis of leukocytes (granulocytes, monocytes and lymphocytes). Different cytokines are also produced (TNF- $\alpha$, IL-1, IL-6 and IL-8), as are nitric oxide, matrix metalloproteinases, eicosanoids (prostaglandins, thromboxanes, leukotrienes, endocannabinoids, lipoxins, eoxines and others), and other products, for example reactive oxygen species (e.g. superoxide anion, hydrogen peroxide), conditional to the cell type involved, type of inflammatory stimulus, the anatomical site involved, and the phase during the inflammatory response [1, 2]. The inflammatory mediators are responsible for local tissue damage, systemic effects on the central nervous system, stimulation of proteolysis in skeletal muscle and lipolysis in adipose tissue, synthesis of acute phase proteins in the liver, and destruction/elimination of pathogens and toxic agents. Following the acute phase of the inflammatory process, it undergoes resolution and recovery. In fact inflammation is usually self-limiting and is often resolved quickly due to the stimulation of negative feedback mechanisms that oppose the inflammatory signal (secretion of anti-inflammatory cytokines or pro-resolving lipid mediators, inhibition of pro-inflammatory signalling cascades, activation of regulatory cells, etc.). Loss of these regulatory processes can result in excessive, inappropriate or on-going inflammation that can cause irreparable damage to host tissues [88-90]. This is the case in different chronic conditions, including well recognised inflammatory diseases like arthritis, but also "lifestyle" diseases such as obesity, CHD, type 2 
diabetes mellitus, and NAFLD, that are characterized by a chronic low-grade inflammatory state [3, 4].

CVDs are the leading cause of death globally. Many risk factors have been described to drive the development of CVDs, including dyslipidaemia, arterial hypertension, smoking, age, male gender, diabetes mellitus, sedentary lifestyle and stress. The most common CVDs are cardiac ischemia and cerebrovascular disease, and atherosclerosis has a key role in the pathogenesis of both of them. Hypercholesterolemia and high blood pressure were considered the main promoters of atherosclerosis for many years. Now there is increasing evidence showing that chronic inflammation is also a key factor in the aetiology of atherosclerosis, which has been described as an unresolved inflammatory condition, missing the shift from pro-inflammatory to anti-inflammatory mediators that features the resolution phase of inflammation [91]. In atherosclerosis development, leukocyte recruitment to the sub-endothelial compartment of impaired arteries starts a sequence of events mediated by leukocyte-derived chemokines and cytokines that propagate atherosclerosis through increased inflammatory mediator production and expression of endothelial adhesion molecules, perpetuating leukocyte recruitment; promoting lipid-laden foam-cell formation; stimulating the proliferation of smooth muscle cells resulting in plaque formation and accumulation and ultimately inducing plaque instability and eventual rupture [92-95]. The subsequent thrombosis also depends on the inflammatory status of the ruptured plaque $[89,94,96]$.

\section{18-carbon TFAs and inflammation}

Dietary FAs may affect inflammatory processes through effects on body weight and adipose tissue mass (since excessive adipose tissue is an inflammatory focus that releases inflammatory mediators into the bloodstream) and through changes in the membrane composition of cells involved in inflammation. Changes in the composition of cell membranes can modify membrane fluidity, lipid raft formation, cell signalling leading to altered gene expression, and the pattern of lipid and peptide mediator production [97]. Within the cell, membrane-derived FAs and their products can influence inflammation by serving as modulators of the nuclear factor kappa beta (NF-k $\beta$ ) and peroxisome proliferator activated receptor (PPAR)- $\alpha / \gamma$ transcription factor pathways related to the expression of genes encoding cytokines and chemokines, some acting in pro-inflammatory and others in antiinflammatory ways [98], and as precursors of eicosanoid and docosanoid oxidation products formed by the action of enzymes like epoxygenases, lipoxygenases and cyclooxygenases [99]. 
In relation to TFAs, the intake of iTFAs is clearly associated with CHD and associated pathologies (see earlier). The involvement of systemic inflammation and endothelial dysfunction in the pathogenesis of atherosclerosis and CVD in general, and the evidence from both observational and experimental studies that iTFAs are pro-inflammatory may provide the explanation. Nevertheless, more studies are required to explain the effects of iTFAs, the possible underlying mechanisms and the implications of such effects on inflammation and cardiovascular health. Regarding rTFAs, some evidence about favourable properties of these compounds in vitro and in animal models of disease (obesity, cancer, diabetes) has been published [100], but the effects in humans are still unclear [101]. Their involvement in the modulation of inflammatory processes is not fully understood, but some studies suggest that TVA and some CLA isomers may be hypocholesterolemic and antiatherogenic $[6,100]$.

\subsection{Human studies of 18-carbon TFAs and inflammation}

\subsubsection{Epidemiological studies}

Observational studies (Table 4) have correlated intake or levels of TFAs with clinical outcomes related to inflammation; some have looked for the differences between iTFAs and rTFAs, although the majority use total TFAs without differentiating between the sources. In 2004 Mozaffarian et al. reported that TFA intake is positively associated with markers of systemic inflammation (soluble tumour necrosis factor $\alpha$ receptors (sTNF-R1 and 2)) in generally healthy women, although most of the TFA intake in the participants of these cohorts came from processed foods (fried foods (18\%); cookies, donuts, or sweet rolls (17\%); margarine (10\%); beef (9\%); and crackers (4\%)), suggesting that they were mainly iTFAs [85]. The same authors also showed that, in patients with chronic heart failure, TFA levels in red blood cell membranes were strongly associated with levels of IL-1, IL-1 receptor antagonist, IL-10, TNF- $\alpha$, sTNF-R1 and 2, monocyte chemoattractant protein 1 (MCP-1) and brain natriuretic peptide, particularly trans isomers of oleic and linoleic acids but not of palmitoleic acid [84]. These findings are consistent with those of Lopez-Garcia et al. in a cross sectional study of 730 healthy women from the Nurses' Health Study I cohort. They showed that TFA intake (more strongly EA) was positively related to plasma concentrations of CRP, sTNF-R2, sE-selectin, sICAM-1, and SVCAM-1 [86].

In contrast, in Danish middle-aged men with a broad body mass index (BMI) range, intake of TFAs was not associated with levels of IL-6 or CRP, blood pressure, insulin sensitivity or blood lipids [102], which could be explained by the fact that reported TFA intakes were relatively low and their source was mainly ruminant fat, given Danish legislation to eliminate food products containing iTFAs since the 1990s and the high intake of milk/dairy products in Denmark. Actually, an 18-year follow-up 
study of 3,686 Danes, aged 30-71 years and healthy at baseline concluded there was no association between rTFA intake and risk of CHD over a wide range of intake [77].

Da Silva et al. compared iTFAs and rTFAs in plasma phospholipids and their correlations with metabolic risk factors, including lipid profile, glycaemic profile, adiposity and blood pressure, in a cohort composed of 100 healthy non-obese and 100 obese Canadian participants. They found that plasma rTFAs (TVA and also trans-palmitoleic acid) levels were associated with lower insulin levels and blood pressure and higher adiponectin levels, unlike the industrial counterpart (EA) which was associated with higher total cholesterol, TAGs and glycaemia, strongly indicating that different sources of TFAs may have different impacts on metabolic markers of cardiac health [103]. Given that adiponectin is anti-inflammatory, these findings suggest that rTFAs reduce inflammation.

A recent cross-sectional study with 5,546 adult participants, using data from the 1999-2000 cycles of the US National Health and Nutrition Examination Surveys, showed that all of the serum TFAs measured (palmitelaidic acid, EA, TVA and linolaidic acid) were independent predictors of plasma Creactive protein and fibrinogen levels [104], and the authors suggested that all sources of TFAs enhance inflammation and should be avoided.

Overall, epidemiological studies do show a positive association between intake or levels of iTFAs and several markers of inflammation, while the evidence for rTFAs, although more conflicting, mostly suggest a null or inverse association.

\subsubsection{Intervention studies}

There are very few intervention studies comparing the effects of iTFAs and rTFAs on biomarkers of inflammation or on inflammatory responses. Additionally, when they are tested individually, doses used, delivery method, intervention duration and washout periods, gender differences, health conditions and age variations of the subjects under study can contribute to the inability to draw clear comparisons between them (Table 5).

In relation to the effects of iTFAs, the double blind crossover study by Han et al., where 19 subjects with moderately elevated LDL cholesterol levels were exposed randomly to 3 diets with the same amount of fat (30\%) but different proportion of iTFAs or saturated fats, reported that a soybean margarine diet ( $6.7 \%$ of energy from iTFAs) increased TNF- $\alpha$ and IL- 6 production by cultured mononuclear cells in comparison with a soybean oil diet (0.6\% of energy from iTFAs) [82]. Similarly, Baer et al. showed that an intake of $8 \%$ of energy $(28.8 \mathrm{~g} / \mathrm{d}$ ) for 5 weeks as TFAs (spectrum of trans 18:1 isomers representative of the US food supply) induced increased blood levels of CRP, IL-6 and 
$\mathrm{SE}-$ selectin in 50 healthy adult males. When half the amount of TFAs (4\% TFAs, $4 \%$ stearic acid) was consumed daily, CRP level did not increase, although fibrinogen levels did, which was suggested to be caused by stearic acid [81]. Another study conducted in overweight postmenopausal women reported that an increased intake of iTFAs ( $7 \%$ of daily energy) for 16 weeks produced an increase in the circulating levels of TNF- $\alpha$ and its soluble receptors TNF-R1 and TNF-R2 [105], with no changes on CRP, IL-6 or adiponectin levels.

In contrast, in the case of rTFAs, Tricon et al. showed that a daily amount of $1.5 \mathrm{~g}$ CLA9,11 and $4.7 \mathrm{~g}$ TVA consumed through modified dairy products for six weeks had no effects on inflammatory biomarkers, insulin, glucose, total cholesterol, and TAGs in serum [9]. Another study used sheep cheese naturally rich in TVA and CLA9,11 for 10 weeks in a small sample of adults reporting a significant reduction in IL-6, IL-8, and TNF- $\alpha$ levels, compared to placebo [8]. Similarly, a study where 29 healthy adult volunteers underwent a CLA depletion followed by an 8 week period consuming 20 g of CLA9,11 enriched butter daily (1020 $\pm 167 \mathrm{mg}$ CLA/day) showed decreased protein expression of Ç록 $\square$ « 輀

of the anti-inflammatory cytokine IL-10 after CLA repletion compared to the levels in the depletion phase [106].

When comparing the effect of the two most common CLA isomers, some studies suggest that CLA10,12 may have pro-inflammatory effects. Tholstrup et al. compared the effects of a CLA mixture, an oil rich in CLA9,11 or olive oil for 16 weeks in healthy postmenopausal women, showing that the oil containing CLA10,12 caused higher plasma levels of CRP, fibrinogen, and plasminogen activator inhibitor-1 (PAI-1) and of a urine marker of lipid peroxidation, compared to the oil rich in natural CLA9,11 and the olive oil [107]. Other authors have also reported increased CRP after CLA10,12 or CLA mix supplementation, whether in obese men with metabolic syndrome [108], obese adults [109] or healthy adults [110]. Nevertheless, the evidence is not consistent. Ramakers et al. found no effects on ex vivo cytokine production by isolated peripheral blood mononuclear cells (PBMCs) or by PBMCs present in whole blood when stimulated with lipopolysaccharide (LPS) from a small sample of moderately overweight subjects at increased risk for CHD, after daily consumption of $3 \mathrm{~g}$ of CLA9,11 or CLA10,12 in an enriched dairy product for 13 weeks [7]. A study testing an enriched butter with CLA9,11 or CLA10,12 for 5 weeks showed increases in lipid peroxidation but no effects on plasma total, LDL, and HDL cholesterol and TAGs, or inflammatory and haemostatic risk markers, nor in fasting insulin and glucose concentrations, in healthy young men [111]. 
One of the few published randomised controlled trials comparing the effects of iTFAs and rTFAs in healthy adults, showed that the intake of enriched dairy products with iTFAs (7\% of energy) or a mix of CLAs for 3 weeks did not affect low-grade inflammation to a large degree (lower sTNF-R1 and higher sE-selectin), while both induced an increased excretion of 8-iso-prostaglandin $\mathrm{F}_{2 \alpha}$, a marker of oxidative stress [112]. In the same way, Radtke et al. reported that $2 \%$ of daily energy intake as TFAs (alpine butter or margarine) or no TFA as control, during 4 weeks, did not have any adverse effect on coagulation, inflammation markers and adhesion molecules in healthy subjects. Nevertheless, the rTFA diet resulted in increased levels of total cholesterol and LDL-cholesterol compared with the other two diets, which may have been caused by some important differences in the nutritional composition between alpine butter and margarine (i.e. the saturated fatty acid, monounsaturated fatty acid and polyunsaturated fatty acid (PUFA) contents). Additionally, the study did not reach the estimated total sample size and the diet of the participants was not controlled [113].

Taken together, these findings indicate that health status of the subjects participating in the studies may influence the inflammation response to TFA exposure.

\subsection{Studies in experimental animals (Table 6)}

In an obesity model in rats (JCR:LA-cp), the animals fed a diet with TVA at 1\% w/w during 8 weeks showed a reduction in body fat, increased insulin sensitivity, lower NAFLD activity scores, together with other metabolic benefits [114]. Another report from the same group compared the effects of TVA and EA in the same animal model showing that both TFAs corrected the impaired IL-2 and TNF- $\alpha$ response to T-cell mitogen stimulation seen in obese rats, but only TVA normalized T-cell stimulated IL-1 $\beta$ and interferon (IFN)- $\gamma$ production and haptoglobin levels. Rats fed with EA produced more IL-6 compared to controls and to TVA fed groups, which was associated with a greater incorporation of EA into splenocyte phospholipids. Additionally, the animals fed with either TFA had higher levels of IL-6 and IL-10, suggesting that both natural and industrial TFAs can facilitate LPS-stimulated immune response in this animal model [115]. Another model in male mice fed for 4 weeks with diets containing $0.5 \% \mathrm{w} / \mathrm{w}$ of TVA, EA or CLA9,11 showed that all TFAs used induced a reduction in body weight and adipose tissue, TVA induced a reduction in LDL cholesterol and TNF- $\alpha$ levels, while CLA9,11 induced higher levels of TNF- $\alpha$ [116].

Other authors have used diets with different amounts of partially hydrogenated oils (rich in EA and/or linoelaidic acid) and reported the effect on different parameters related to inflammation. Longhi et al., using diets with low and high content of lipids in the form of lard or partially 
hydrogenated soybean oil (PHSO), showed that PHSO diets (high and low) increased oxidised LDL levels in serum and cerebrospinal fluid. Additionally, animals fed with PHSO diets had higher levels of IL-1, IL-6 and TNF- $\alpha$ in cerebrospinal fluid, showed impairment of insulin sensitivity and alteration in the antioxidant enzyme activities in hepatic tissue [117]. Another study, using diets rich in $\alpha$-linolenic acid, partially hydrogenated vegetable fat (PHVF) or both mixed in different proportions, reported higher levels of prostaglandin $E_{2}$, thromboxane $B_{2}$, leukotriene $B_{4}$ and leukotriene $C_{4}$, upregulation of cyclooxygenase-2, phospholipase A2 and NF-K $\beta$ p 65 and downregulation of PPAR $\gamma$ in macrophages of rats fed with PHVF. These effects were to different extents normalised by including $\alpha$-linolenic acid in the PHVF diet [118]. In agreement, when longer chain omega-3 FAs (eicosapentaenoic acid (EPA) and docosahexaenoic acid (DHA)) were compared with iTFAs in a model of myocardial infarction, Siddiqui et al. reported that iTFAs adversely affected survival, while omega-3 FAs had beneficial effects on survival. In addition, animals fed with TFAs had variable degrees of aortic atherosclerotic lesions, lacked the ability to develop collaterals around the site of occlusion and showed increased circulating levels of sICAM-1, the opposite to what was observed in the animals fed with omega-3 FA-enriched diet [119].

Studies using CLAs show inconsistent results. Poirier et al. reported that the administration of CLA10,12 by gavage at a dose of $20 \mathrm{mg} /$ day for 7 days in mice led to the upregulation of TNF- $\alpha$, MCP-1 and IL-6 gene expression in white adipose tissue without affecting their serum levels, together with macrophage infiltration in white adipose tissue, reduction in body weight and adipose tissue mass, lower serum levels of leptin, adiponectin and higher levels of insulin and resistin [120]. Similarly, another study, using enriched diets with $0.06 \%, 0.2 \%$, and $0.6 \% \mathrm{w} / \mathrm{w}$ of mixed CLA10,12 with linoleic acid (50/50), mixed CLA10,12 with CLA9,11 (50/50) or linoleic acid alone as a control in young male mice for 6 weeks, showed that the intermediate and higher intakes of CLA10,12 reduced adiposity, increased serum levels of MCP-1 and IL-6 and increased liver steatosis [121]. The apparently paradoxical observations of less adiposity but more liver steatosis may indicate that CLA10,12 promotes retention of TAGs in the liver rather than allowing them to be exported and deposited in adipose tissue. This could be the result of an altered hormonal milieu and changes to lipid and carbohydrate metabolism caused by CLA10,12.

In two murine models of arthritis, collagen antibody-induced arthritis and collagen-induced arthritis, where the mice were exposed to CLAs prior to the induction of joint swelling or after the onset of disease, respectively, both CLA isomers showed anti-inflammatory effects [122, 123]. In contrast, in another model where the mice were exposed to the CLA isomers prior to the onset of arthritis, the diet enriched with CLA10,12 $(0.25 \% \mathrm{w} / \mathrm{w})$ resulted in a more severe initial inflammatory response at the onset of disease. Instead, CLA9,11 (0.5\% w/w) reduced the incidence of the disease by $39 \%$ 
compared to control mice fed with corn oil, also increasing IL-4 and IL-10 levels in the animals paws. The authors suggested that CLA10,12 may have acted by driving Th1 type responses during the adaptive immune response, whereas CLA9,11 may have induced a Th2 dominant adaptive immune response [124].

Studies in animal models show more consistent outcomes relating the exposure to CLA9,11 and antiinflammatory responses. Using a murine asthma model, colorectal cancer in mice and a model of LPS-induced inflammation in mice, CLA9,11 induced a reduction in the allergic airway inflammation, decreased percentages of macrophages in the mesenteric lymph nodes and downregulation of colonic TNF- $\alpha$ mRNA expression, and reduced the serum levels of the proinflammatory cytokines IFN- $\gamma$, IL-12, and IL-1 $\beta$, in response to LPS-induced septic shock [125-127].

In summary, animal studies suggest that iTFAs promote pro-inflammatory responses, and increase oxidative stress and vascular dysfunction together with other metabolic alterations. In the case of rTFAs the results are diverse, TVA and CLA9,11 usually exhibit some beneficial effect in terms of metabolism and/or inflammation, while the CLA10,12 isomer, depending on the concentration and model used, showed detrimental, but also beneficial, effects in terms of inflammation.

\subsection{Studies in vitro}

In unstimulated human umbilical vein endothelial cells (HUVECs) and human aortic endothelial cells (HAECs), linoelaidic acid and/or EA have been shown to induce gene expression, surface expression or protein levels of ICAM-1, VCAM-1, IL-6 and toll-like receptor (TLR)-4, the phosphorylation and nuclear translocation of NF-K $\beta$ p65 and IK $\beta \alpha$, the adhesion of monocytes and lymphocytes, and to impair insulin-mediated nitric oxide production together with increased reactive oxygen species production [128-131] as depicted in Table 7. In contrast, studies using TVA in HUVECs or human microvascular endothelial cells (HMECs) found no effects on or downregulation of inflammatory gene expression $[128,132,133]$. When HepG2 cells are exposed to a pro-inflammatory stimulus, TVA was shown to downregulate TNF- $\alpha$ and IL-8 genes [134].

However, there are reports describing some similar effects of iTFAs and rTFAs in different cell models (both anti and pro-inflammatory). For example, Da Silva et al. showed that both TVA $(25,50$ and $150 \mu \mathrm{M}$ ) and EA ( 5 to $150 \mu \mathrm{M}$ ) downregulated gene expression of TNF, VCAM-1 and superoxide dismutase (SOD)-2 together with reducing the secretion of prostaglandin $E_{2}$ in HUVECs stimulated with TNF- $\alpha$ [134]. In another model of human coronary arterial smooth muscle cells (HCASMCs), a high concentration of TVA and EA ( $200 \mu \mathrm{M}$ for $20 \mathrm{~h}$ ) increased the levels of IL-6 and MCP-1, respectively [135]. 
In relation to the effects of CLAs, some studies have reported anti-inflammatory effects in HUVECs. Sneddon et al. reported that CLA10,12 was able to suppress adhesion of THP-1 cells and isolated human PBMCs dose-dependently in HUVECs treated with TNF- $\alpha$, which was related to the suppression of platelet-activating factor production [136]. Similarly, Goua et al. showed that CLA10,12 and a CLA mix reduced ICAM-1 and VCAM-1 expression, while the CLA mix used at $25 \mu \mathrm{M}$ was able to decrease NF-kB activity by $30 \%$ in both HUVECs and smooth muscle cells treated with TNF- $\alpha$ [137]. Another study by Stachowska et al. showed that the incubation of monocytes from healthy donors with CLA9,11 and CLA10,12 at $100 \mu \mathrm{M}$ for 7 days reduced the expression of the integrins VLA-4 and Mac-1. When HUVECs were exposed to the same concentrations of CLA isomers, both caused a reduction in the surface expression of VCAM-1, but only CLA9,11 reduced ICAM-1 compared to control. Additionally, both CLA isomers showed a strong tendency to reduce the binding of monocytes to HUVECs [138].

It is difficult to compare in vitro studies testing the effects of 18-carbon TFAs on inflammatory processes, given the methodological differences between them: TFA used, TFA concentrations, preparation of TFA solutions, time of exposure, type of cells, use or not of an inflammatory stimulus. Nevertheless, in general, the studies reviewed here show that iTFAs have pro-inflammatory effects, while rTFAs usually have null or the opposite effects to iTFAs in these models.

\section{Summary and perspective}

iTFAs have been present in Western diets for the last century, although their negative effects on health were not described until the early 1990s, when Mensink and Katan showed an increase in LDL cholesterol and decreased HDL cholesterol in healthy subjects in relation to iTFA exposure [139]. The physical structure of iTFAs makes them more similar to saturated FAs, and this may be related to their effects on blood lipids. The effects of iTFAs on systemic inflammation started to be reported in the 2000s, from observational and experimental studies, showing increases in different proinflammatory cytokines in hypercholesterolemic patients and in healthy subjects. Even though their intake and levels have been shown to be decreasing in some countries, there are still large groups of the population with a high exposure to iTFAs, especially those consuming high and frequent amounts of take away or ultra-processed foods.

The evidence associating iTFAs with CVD risk factors is fairly consistent. Regarding inflammatory processes or markers, studies in humans usually show a relation between higher iTFA intake or levels with higher concentrations of pro-inflammatory markers. 
In contrast to iTFAs, rTFAs have been present in the human diet for centuries, in ruminant meat, and their milk and milk products; nevertheless, their effects on health in general and inflammation in particular were not studied extensively or differentiated from effects of iTFAs until recently. In fact, the current recommendation of eating $<1 \%$ of daily energy as TFAs does not distinguish between types of TFA (ruminant vs industrial), when there is evidence that their effects may be opposite.

Overall, studies in humans, animals and in vitro suggest that rTFAs have null or mildly beneficial effects in cardiovascular health, metabolic parameters and inflammatory markers, although the evidence is not always consistent.

The mechanisms by which 18-carbon TFAs exert their effects on inflammation suggested to date involve the NF-K $\beta$ pathway, with a possible role for TLR-4, PPARs, lipid raft formation and changes in oxidative stress $[118,120,128-131,133,137,140]$. These mechanisms are summarised in Figure 4. Future research should consider that the health effects are dependent upon the species of TFA, its concentration and the duration of exposure. Another factor to consider is the food matrix where the TFAs are found, because when a single type of TFA is tested, the effects do not always match with those when the TFA is administered in a food matrix, as consumed normally. It is also possible that other compounds generated in the industrial processes involved in the production of TFAs or in the matrix of dairy products may contribute to their detrimental or beneficial effects, respectively. Long term randomised controlled trials, with an initial depletion period, measuring basal and post intervention levels of the TFAs tested, with long enough wash out periods, controlling TFA intake and the diet of the participants, with isocaloric interventions and an adequate nutrient replacement in the control group might be necessary in the future to correctly identify the beneficial and detrimental effects of the different types TFAs.

With the evidence available now it is not possible to establish public health dietary guidelines related to the intake of rTFAs, although most of the studies in humans show no detrimental effects. Given that dairy products provide many other necessary and important nutrients for human nutrition (i.e. calcium, iodine, vitamin B12, fat-soluble vitamins, essential amino acids, etc.), their consumption should not be restricted by only considering their contribution to TFA intake. 


\section{References}

[1] P.C. Calder, R. Albers, J.M. Antoine, S. Blum, R. Bourdet-Sicard, G.A. Ferns, G. Folkerts, P.S. Friedmann, G.S. Frost, F. Guarner, M. Lovik, S. Macfarlane, P.D. Meyer, L. M'Rabet, M. Serafini, W. van Eden, J. van Loo, W. Vas Dias, S. Vidry, B.M. Winklhofer-Roob, J. Zhao, Inflammatory disease processes and interactions with nutrition, Br J Nutr 101 Suppl 1 (2009) S1-45.

[2] P.C. Calder, N. Ahluwalia, R. Albers, N. Bosco, R. Bourdet-Sicard, D. Haller, S.T. Holgate, L.S. Jonsson, M.E. Latulippe, A. Marcos, J. Moreines, C. M'Rini, M. Muller, G. Pawelec, R.J. van Neerven, B. Watzl, J. Zhao, A consideration of biomarkers to be used for evaluation of inflammation in human nutritional studies, Br J Nutr 109 Suppl 1 (2013) S1-34.

[3] G.S. Hotamisligil, Inflammation and metabolic disorders, Nature 444(7121) (2006) 860-7.

[4] M.F. Gregor, G.S. Hotamisligil, Inflammatory mechanisms in obesity, Annu Rev Immunol 29 (2011) 415-45.

[5] S.K. Gebauer, T.L. Psota, P.M. Kris-Etherton, The diversity of health effects of individual trans fatty acid isomers, Lipids 42(9) (2007) 787-99.

[6] S.K. Gebauer, J.M. Chardigny, M.U. Jakobsen, B. Lamarche, A.L. Lock, S.D. Proctor, D.J. Baer, Effects of ruminant trans fatty acids on cardiovascular disease and cancer: a comprehensive review of epidemiological, clinical, and mechanistic studies, Advances in nutrition (Bethesda, Md.) 2(4) (2011) 332-54.

[7] J.D. Ramakers, J. Plat, J.L. Sebedio, R.P. Mensink, Effects of the individual isomers cis-9,trans-11 vs. trans-10,cis-12 of conjugated linoleic acid (CLA) on inflammation parameters in moderately overweight subjects with LDL-phenotype B, Lipids 40(9) (2005) 909-18.

[8] F. Sofi, A. Buccioni, F. Cesari, A.M. Gori, S. Minieri, L. Mannini, A. Casini, G.F. Gensini, R. Abbate, $M$. Antongiovanni, Effects of a dairy product (pecorino cheese) naturally rich in cis-9, trans-11 conjugated linoleic acid on lipid, inflammatory and haemorheological variables: a dietary intervention study, Nutrition, metabolism, and cardiovascular diseases : NMCD 20(2) (2010) 117-24. [9] S. Tricon, G.C. Burdge, E.L. Jones, J.J. Russell, S. El-Khazen, E. Moretti, W.L. Hall, A.B. Gerry, D.S. Leake, R.F. Grimble, C.M. Williams, P.C. Calder, P. Yaqoob, Effects of dairy products naturally enriched with cis-9,trans-11 conjugated linoleic acid on the blood lipid profile in healthy middle-aged men, Am J Clin Nutr 83(4) (2006) 744-53.

[10] WHO, Global Health Estimates 2016: Deaths by Cause, Age, Sex, by Country and by Region, 2000-2016. Geneva, World Health Organization., 2018.

[11] T.A. Ghebreyesus, T.R. Frieden, REPLACE: a roadmap to make the world trans fat free by 2023, Lancet 391(10134) (2018) 1978-1980.

[12] WHO, Eliminating trans fats in Europe. A policy brief. Copenhagen: World Health Organization Regional Office for Europe, 2015.

[13] EFSA, Scientific and technical assistance on trans fatty acids, EFSA Supporting Publications 15(6) (2018) 1433E.

[14] A. Astrup, The trans fatty acid story in Denmark, Atherosclerosis. Supplements 7(2) (2006) 43-6.

[15] K.W. Wahle, S.D. Heys, D. Rotondo, Conjugated linoleic acids: are they beneficial or detrimental to health?, Prog Lipid Res 43(6) (2004) 553-87.

[16] A. Valenzuela, N. Morgado, Trans fatty acid isomers in human health and in the food industry, Biological research 32(4) (1999) 273-87.

[17] J.-M. Chardigny, P. Clouet, N. Combe, A. Quignard-Boulangé, B. Schmitt, M. Lagarde, C.-L. Léger, Metabolism of trans and conjugated fatty acids, European Journal of Lipid Science and Technology 109(9) (2007) 930-934.

[18] A.M. Turpeinen, M. Mutanen, A. Aro, I. Salminen, S. Basu, D.L. Palmquist, J.M. Griinari, Bioconversion of vaccenic acid to conjugated linoleic acid in humans, Am J Clin Nutr 76(3) (2002) 504-10.

[19] E.E. Mosley, M.K. McGuire, J.E. Williams, M.A. McGuire, Cis-9, trans-11 conjugated linoleic acid is synthesized from vaccenic acid in lactating women, J Nutr 136(9) (2006) 2297-301. 
[20] E.E. Mosley, B. Shafii Dagger, P.J. Moate, M.A. McGuire, cis-9, trans-11 conjugated linoleic acid is synthesized directly from vaccenic acid in lactating dairy cattle, J Nutr 136(3) (2006) 570-5.

[21] J.M. Griinari, B.A. Corl, S.H. Lacy, P.Y. Chouinard, K.V. Nurmela, D.E. Bauman, Conjugated linoleic acid is synthesized endogenously in lactating dairy cows by Delta(9)-desaturase, J Nutr 130(9) (2000) 2285-91.

[22] J.E. Santora, D.L. Palmquist, K.L. Roehrig, Trans-vaccenic acid is desaturated to conjugated linoleic acid in mice, J Nutr 130(2) (2000) 208-15.

[23] T.P. Krogager, L.V. Nielsen, D. Kahveci, T.F. Dyrlund, C. Scavenius, K.W. Sanggaard, J.J. Enghild, Hepatocytes respond differently to major dietary trans fatty acid isomers, elaidic acid and transvaccenic acid, Proteome Sci 13 (2015) 31.

[24] J.L. Sebedio, P. Juaneda, G. Dobson, I. Ramilison, J.C. Martin, J.M. Chardigny, W.W. Christie, Metabolites of conjugated isomers of linoleic acid (CLA) in the rat, Biochim Biophys Acta 1345(1) (1997) 5-10.

[25] S. Banni, G. Carta, E. Angioni, E. Murru, P. Scanu, M.P. Melis, D.E. Bauman, S.M. Fischer, C. Ip, Distribution of conjugated linoleic acid and metabolites in different lipid fractions in the rat liver, J Lipid Res 42(7) (2001) 1056-61.

[26] P. Juaneda, J.L. Sebedio, Combined silver-ion and reversed-phase high-performance liquid chromatography for the separation and identification of C20 metabolites of conjugated linoleic acid isomers in rat liver lipids, Journal of chromatography. B, Biomedical sciences and applications 724(2) (1999) 213-9.

[27] P.C. Calder, Functional Roles of Fatty Acids and Their Effects on Human Health, JPEN J Parenter Enteral Nutr 39(1 Suppl) (2015) 18S-32S.

[28] E.A. Emken, Nutrition and biochemistry of trans and positional fatty acid isomers in hydrogenated oils, Annual review of nutrition 4 (1984) 339-76.

[29] A. Ascherio, W.C. Willett, Health effects of trans fatty acids, The American journal of clinical nutrition 66(4 Suppl) (1997) 1006s-1010s.

[30] R. Ganguly, G.N. Pierce, The toxicity of dietary trans fats, Food and chemical toxicology : an international journal published for the British Industrial Biological Research Association 78 (2015) 170-6.

[31] V. Remig, B. Franklin, S. Margolis, G. Kostas, T. Nece, J.C. Street, Trans fats in America: a review of their use, consumption, health implications, and regulation, J Am Diet Assoc 110(4) (2010) 585-92. [32] W. Tsuzuki, A. Matsuoka, K. Ushida, Formation of trans fatty acids in edible oils during the frying and heating process, Food Chemistry 123(4) (2010) 976-982.

[33] M. Tasan, M. Demirci, Trans FA in sunflower oil at different steps of refining, Journal of the American Oil Chemists' Society 80(8) (2003) 825-828.

[34] W.M. Ratnayake, M.R. L'Abbe, S. Farnworth, L. Dumais, C. Gagnon, B. Lampi, V. Casey, D. Mohottalage, I. Rondeau, L. Underhill, M. Vigneault, W. Lillycrop, M. Meleta, L.Y. Wong, T. Ng, Y. Gao, K. Kwong, S. Chalouh, P. Pantazopoulos, H. Gunaratna, A. Rahardja, R. Blagden, V. Roscoe, T. Krakalovich, G. Neumann, G.A. Lombaert, Trans fatty acids: current contents in Canadian foods and estimated intake levels for the Canadian population, Journal of AOAC International 92(5) (2009) 1258-76.

[35] C.J. Field, H.H. Blewett, S. Proctor, D. Vine, Human health benefits of vaccenic acid, Applied physiology, nutrition, and metabolism = Physiologie appliquee, nutrition et metabolisme 34(5) (2009) 979-91.

[36] K. Kuhnt, C. Degen, G. Jahreis, Evaluation of the Impact of Ruminant Trans Fatty Acids on Human Health: Important Aspects to Consider, Critical reviews in food science and nutrition 56(12) (2016) 1964-80.

[37] D.B. Allison, S.K. Egan, L.M. Barraj, C. Caughman, M. Infante, J.T. Heimbach, Estimated intakes of trans fatty and other fatty acids in the US population, J Am Diet Assoc 99(2) (1999) 166-74; quiz 1756. 
[38] S.L. Elias, S.M. Innis, Bakery foods are the major dietary source of trans-fatty acids among pregnant women with diets providing 30 percent energy from fat, J Am Diet Assoc 102(1) (2002) 4651.

[39] W.S. Harris, J.V. Pottala, R.S. Vasan, M.G. Larson, S.J. Robins, Changes in erythrocyte membrane trans and marine fatty acids between 1999 and 2006 in older Americans, J Nutr 142(7) (2012) 1297303.

[40] S. Mendis, C. Cruz-Hernandez, W.M. Ratnayake, Fatty acid profile of Canadian dairy products with special attention to the trans-octadecenoic acid and conjugated linoleic acid isomers, Journal of AOAC International 91(4) (2008) 811-9.

[41] G.K. Pot, C.J. Prynne, C. Roberts, A. Olson, S.K. Nicholson, C. Whitton, B. Teucher, B. Bates, H. Henderson, S. Pigott, National Diet and Nutrition Survey: fat and fatty acid intake from the first year of the rolling programme and comparison with previous surveys, British Journal of Nutrition 107(03) (2012) 405-415.

[42] M. Vadiveloo, M. Scott, P. Quatromoni, P. Jacques, N. Parekh, Trends in dietary fat and high-fat food intakes from 1991 to 2008 in the Framingham Heart Study participants, Br J Nutr 111(4) (2014) 724-34.

[43] K.F. Hulshof, M.A. van Erp-Baart, M. Anttolainen, W. Becker, S.M. Church, C. Couet, E. HermannKunz, H. Kesteloot, T. Leth, I. Martins, O. Moreiras, J. Moschandreas, L. Pizzoferrato, A.H. Rimestad, H. Thorgeirsdottir, J.M. van Amelsvoort, A. Aro, A.G. Kafatos, D. Lanzmann-Petithory, G. van Poppel, Intake of fatty acids in western Europe with emphasis on trans fatty acids: the TRANSFAIR Study, Eur J Clin Nutr 53(2) (1999) 143-57.

[44] M.G. Enig, S. Atal, M. Keeney, J. Sampugna, Isomeric trans fatty acids in the U.S. diet, Journal of the American College of Nutrition 9(5) (1990) 471-86.

[45] D. Doell, D. Folmer, H. Lee, M. Honigfort, S. Carberry, Updated estimate of trans fat intake by the US population, Food Additives \& Contaminants: Part A 29(6) (2012) 861-874.

[46] P.M. Kris-Etherton, M. Lefevre, R.P. Mensink, B. Petersen, J. Fleming, B.D. Flickinger, Trans Fatty Acid Intakes and Food Sources in the U.S. Population: NHANES 1999-2002, Lipids 47(10) (2012) 931940.

[47] M.U. Jakobsen, A. Bysted, N.L. Andersen, B.L. Heitmann, H.B. Hartkopp, T. Leth, K. Overvad, J. Dyerberg, Intake of ruminant trans fatty acids in the Danish population aged 1-80 years, Eur J Clin Nutr 60(3) (2006) 312-8.

[48] S. Stender, A. Astrup, J. Dyerberg, Ruminant and industrially produced trans fatty acids: health aspects, Food \& nutrition research 52 (2008).

[49] R. Ringseis, A. Muller, K. Dusterloh, S. Schleser, K. Eder, H. Steinhart, Formation of conjugated linoleic acid metabolites in human vascular endothelial cells, Biochim Biophys Acta 1761(3) (2006) 377-83.

[50] Commission Regulation (EU) 2019/649 of 24 April 2019 amending Annex III to Regulation (EC) No 1925/2006 of the European Parliament and of the Council as regards trans fat, other than trans fat naturally occurring in fat of animal origin, in: T.E. Commission (Ed.) Official Journal of the European Union, 2019.

[51] R.H. Eckel, S. Borra, A.H. Lichtenstein, S.Y. Yin-Piazza, Understanding the complexity of trans fatty acid reduction in the American diet: American Heart Association Trans Fat Conference 2006: report of the Trans Fat Conference Planning Group, Circulation 115(16) (2007) 2231-46.

[52] P.M. Kris-Etherton, S. Innis, A. Ammerican Dietetic, C. Dietitians of, Position of the American Dietetic Association and Dietitians of Canada: dietary fatty acids, Journal of the American Dietetic Association 107(9) (2007) 1599-611.

[53] A.H. Lichtenstein, L.J. Appel, M. Brands, M. Carnethon, S. Daniels, H.A. Franch, B. Franklin, P. Kris-Etherton, W.S. Harris, B. Howard, N. Karanja, M. Lefevre, L. Rudel, F. Sacks, L. Van Horn, M. Winston, J. Wylie-Rosett, Diet and lifestyle recommendations revision 2006: a scientific statement from the American Heart Association Nutrition Committee, Circulation 114(1) (2006) 82-96. 
[54] Third Report of the National Cholesterol Education Program (NCEP) Expert Panel on Detection, Evaluation, and Treatment of High Blood Cholesterol in Adults (Adult Treatment Panel III) final report, Circulation 106(25) (2002) 3143-421.

[55] S.A. Abdelmagid, D.E. Nielsen, A. Badawi, A. El-Sohemy, D.M. Mutch, D.W. Ma, Circulating concentrations and relative percent composition of trans fatty acids in healthy Canadian young adults between 2004 and 2010: a cross-sectional study, CMAJ open 5(1) (2017) E130-e136.

[56] H.W. Vesper, S.P. Caudill, H.C. Kuiper, Q. Yang, N. Ahluwalia, D.A. Lacher, J.L. Pirkle, Plasma trans-fatty acid concentrations in fasting adults declined from NHANES 1999-2000 to 2009-2010, Am J Clin Nutr 105(5) (2017) 1063-1069.

[57] M. Matejcic, F. Lesueur, C. Biessy, A.L. Renault, N. Mebirouk, S. Yammine, P. Keski-Rahkonen, K. Li, B. Hemon, E. Weiderpass, V. Rebours, M.C. Boutron-Ruault, F. Carbonnel, R. Kaaks, V. Katzke, T. Kuhn, H. Boeing, A. Trichopoulou, D. Palli, C. Agnoli, S. Panico, R. Tumino, C. Sacerdote, J.R. Quiros, E.J. Duell, M. Porta, M.J. Sanchez, M.D. Chirlaque, A. Barricarte, P. Amiano, W. Ye, P.H. Peeters, K.T. Khaw, A. Perez-Cornago, T.J. Key, H.B. Bueno-de-Mesquita, E. Riboli, P. Vineis, I. Romieu, M.J. Gunter, V. Chajes, Circulating plasma phospholipid fatty acids and risk of pancreatic cancer in a large European cohort, International journal of cancer 143(10) (2018) 2437-2448.

[58] G.C. Burdge, B. Lupoli, J.J. Russell, S. Tricon, S. Kew, T. Banerjee, K.J. Shingfield, D.E. Beever, R.F. Grimble, C.M. Williams, P. Yaqoob, P.C. Calder, Incorporation of cis-9,trans-11 or trans-10,cis-12 conjugated linoleic acid into plasma and cellular lipids in healthy men, J Lipid Res 45(4) (2004) 73641.

[59] G.C. Burdge, S. Tricon, R. Morgan, K.E. Kliem, C. Childs, E. Jones, J.J. Russell, R.F. Grimble, C.M. Williams, P. Yaqoob, P.C. Calder, Incorporation of cis-9, trans-11 conjugated linoleic acid and vaccenic acid (trans-11 $18: 1$ ) into plasma and leucocyte lipids in healthy men consuming dairy products naturally enriched in these fatty acids, Br J Nutr 94(2) (2005) 237-43.

[60] G.C. Burdge, P.R. Derrick, J.J. Russell, S. Tricon, S. Kew, T. Banerjee, R.F. Grimble, C.M. Williams, P. Yaqoob, P.C. Calder, Incorporation of cis-9, trans-11 or trans-10, cis-12 conjugated linoleic acid into human erythrocytes in vivo, Nutrition Research 25(1) (2005) 13-19.

[61] X.R. Liu, Z.Y. Deng, J.N. Hu, Y.W. Fan, R. Liu, J. Li, J.T. Peng, H. Su, Q. Peng, W.F. Li, Erythrocyte membrane trans-fatty acid index is positively associated with a 10 -year $\mathrm{CHD}$ risk probability, $\mathrm{Br} \mathrm{J}$ Nutr 109(9) (2013) 1695-703.

[62] C. von Schacky, A. Passow, R. Kiefl, Trans-fatty acid levels in erythrocytes in Europe, Eur J Nutr 56(4) (2017) 1719-1723.

[63] P.M. Clifton, J.B. Keogh, M. Noakes, Trans fatty acids in adipose tissue and the food supply are associated with myocardial infarction, J Nutr 134(4) (2004) 874-9.

[64] L.A. Smit, A. Baylin, H. Campos, Conjugated linoleic acid in adipose tissue and risk of myocardial infarction, Am J Clin Nutr 92(1) (2010) 34-40.

[65] M.U. Jakobsen, A. Gorst-Rasmussen, H.H. Eriksen, J. Stegger, A.M. Joensen, A. Tjonneland, J. Dyerberg, E.B. Schmidt, K. Overvad, Trans fatty acids in adipose tissue and risk of myocardial infarction: A case-cohort study, PLoS One 13(8) (2018) e0202363.

[66] A.S.D. Laursen, C.C. Dahm, S.P. Johnsen, E.B. Schmidt, K. Overvad, M.U. Jakobsen, Adipose tissue fatty acids present in dairy fat and risk of stroke: the Danish Diet, Cancer and Health cohort, Eur J Nutr 58(2) (2019) 529-539.

[67] R. de Souza Santos da Costa, F. da Silva Santos, D. de Barros Mucci, T.V. de Souza, F.L. de Carvalho Sardinha, C.R. Moutinho de Miranda Chaves, M. das Gracas Tavares do Carmo, trans Fatty Acids in Colostrum, Mature Milk and Diet of Lactating Adolescents, Lipids 51(12) (2016) 1363-1373. [68] P. Gomez-Cortes, M.A. de la Fuente, Classification of Human Milks Based on Their Trans 18:1 Fatty Acid Profile and Effect of Maternal Diet, Breastfeeding medicine : the official journal of the Academy of Breastfeeding Medicine 12 (2017) 238-243.

[69] S.A. Abdelmagid, S.E. Clarke, D.E. Nielsen, A. Badawi, A. El-Sohemy, D.M. Mutch, D.W. Ma, Comprehensive profiling of plasma fatty acid concentrations in young healthy Canadian adults, PLoS One 10(2) (2015) e0116195. 
[70] D. Mozaffarian, M.B. Katan, A. Ascherio, M.J. Stampfer, W.C. Willett, Trans fatty acids and cardiovascular disease, N Engl J Med 354(15) (2006) 1601-13.

[71] W.C. Willett, M.J. Stampfer, J.E. Manson, G.A. Colditz, F.E. Speizer, B.A. Rosner, L.A. Sampson, C.H. Hennekens, Intake of trans fatty acids and risk of coronary heart disease among women, Lancet 341(8845) (1993) 581-5.

[72] F.B. Hu, M.J. Stampfer, J.E. Manson, E. Rimm, G.A. Colditz, B.A. Rosner, C.H. Hennekens, W.C. Willett, Dietary fat intake and the risk of coronary heart disease in women, N Engl J Med 337(21) (1997) 1491-9.

[73] K. Oh, F.B. Hu, J.E. Manson, M.J. Stampfer, W.C. Willett, Dietary fat intake and risk of coronary heart disease in women: 20 years of follow-up of the nurses' health study, Am J Epidemiol 161(7) (2005) 672-9.

[74] Q. Sun, J. Ma, H. Campos, S.E. Hankinson, J.E. Manson, M.J. Stampfer, K.M. Rexrode, W.C. Willett, F.B. Hu, A prospective study of trans fatty acids in erythrocytes and risk of coronary heart disease, Circulation 115(14) (2007) 1858-65.

[75] A. Ascherio, C.H. Hennekens, J.E. Buring, C. Master, M.J. Stampfer, W.C. Willett, Trans-fatty acids intake and risk of myocardial infarction, Circulation 89(1) (1994) 94-101.

[76] P. Pietinen, A. Ascherio, P. Korhonen, A.M. Hartman, W.C. Willett, D. Albanes, J. Virtamo, Intake of fatty acids and risk of coronary heart disease in a cohort of Finnish men. The Alpha-Tocopherol, Beta-Carotene Cancer Prevention Study, Am J Epidemiol 145(10) (1997) 876-87.

[77] M.U. Jakobsen, K. Overvad, J. Dyerberg, B.L. Heitmann, Intake of ruminant trans fatty acids and risk of coronary heart disease, International journal of epidemiology 37(1) (2008) 173-82.

[78] C.M. Oomen, M.C. Ocké, E.J.M. Feskens, M.-A.J.v. Erp-Baart, F.J. Kok, D. Kromhout, Association between trans fatty acid intake and 10-year risk of coronary heart disease in the Zutphen Elderly Study: a prospective population-based study, The Lancet 357(9258) (2001) 746-751.

[79] D. Mozaffarian, R. Clarke, Quantitative effects on cardiovascular risk factors and coronary heart disease risk of replacing partially hydrogenated vegetable oils with other fats and oils, Eur J Clin Nutr 63 Suppl 2 (2009) S22-33.

[80] R.P. Mensink, P.L. Zock, A.D. Kester, M.B. Katan, Effects of dietary fatty acids and carbohydrates on the ratio of serum total to HDL cholesterol and on serum lipids and apolipoproteins: a metaanalysis of 60 controlled trials, Am J Clin Nutr 77(5) (2003) 1146-55.

[81] D.J. Baer, J.T. Judd, B.A. Clevidence, R.P. Tracy, Dietary fatty acids affect plasma markers of inflammation in healthy men fed controlled diets: a randomized crossover study, Am J Clin Nutr 79(6) (2004) 969-73.

[82] S.N. Han, L.S. Leka, A.H. Lichtenstein, L.M. Ausman, E.J. Schaefer, S.N. Meydani, Effect of hydrogenated and saturated, relative to polyunsaturated, fat on immune and inflammatory responses of adults with moderate hypercholesterolemia, J Lipid Res 43(3) (2002) 445-52.

[83] A.H. Lichtenstein, A.T. Erkkila, B. Lamarche, U.S. Schwab, S.M. Jalbert, L.M. Ausman, Influence of hydrogenated fat and butter on CVD risk factors: remnant-like particles, glucose and insulin, blood pressure and C-reactive protein, Atherosclerosis 171(1) (2003) 97-107.

[84] D. Mozaffarian, E.B. Rimm, I.B. King, R.L. Lawler, G.B. McDonald, W.C. Levy, trans fatty acids and systemic inflammation in heart failure, Am J Clin Nutr 80(6) (2004) 1521-5.

[85] D. Mozaffarian, T. Pischon, S.E. Hankinson, N. Rifai, K. Joshipura, W.C. Willett, E.B. Rimm, Dietary intake of trans fatty acids and systemic inflammation in women, Am J Clin Nutr 79(4) (2004) 606-12.

[86] E. Lopez-Garcia, M.B. Schulze, J.B. Meigs, J.E. Manson, N. Rifai, M.J. Stampfer, W.C. Willett, F.B. $\mathrm{Hu}$, Consumption of trans fatty acids is related to plasma biomarkers of inflammation and endothelial dysfunction, J Nutr 135(3) (2005) 562-6.

[87] N.M. de Roos, M.L. Bots, M.B. Katan, Replacement of dietary saturated fatty acids by trans fatty acids lowers serum HDL cholesterol and impairs endothelial function in healthy men and women, Arteriosclerosis, thrombosis, and vascular biology 21(7) (2001) 1233-7. 
[88] C. Galli, P.C. Calder, Effects of fat and fatty acid intake on inflammatory and immune responses: a critical review, Ann Nutr Metab 55(1-3) (2009) 123-39.

[89] A.M. Minihane, S. Vinoy, W.R. Russell, A. Baka, H.M. Roche, K.M. Tuohy, J.L. Teeling, E.E. Blaak, M. Fenech, D. Vauzour, H.J. McArdle, B.H. Kremer, L. Sterkman, K. Vafeiadou, M.M. Benedetti, C.M. Williams, P.C. Calder, Low-grade inflammation, diet composition and health: current research evidence and its translation, The British journal of nutrition 114(7) (2015) 999-1012.

[90] P.C. Calder, Marine omega-3 fatty acids and inflammatory processes: Effects, mechanisms and clinical relevance, Biochim Biophys Acta 1851(4) (2015) 469-84.

[91] J. Viola, O. Soehnlein, Atherosclerosis - A matter of unresolved inflammation, Semin Immunol 27(3) (2015) 184-93.

[92] C.K. Glass, J.L. Witztum, Atherosclerosis. the road ahead, Cell 104(4) (2001) 503-16.

[93] R. Ross, Atherosclerosis - An Inflammatory Disease, New England Journal of Medicine 340(2) (1999) 115-126.

[94] J.M. Hallenbeck, G.K. Hansson, K.J. Becker, Immunology of ischemic vascular disease: plaque to attack, Trends Immunol 26(10) (2005) 550-6.

[95] G.K. Hansson, Inflammation, Atherosclerosis, and Coronary Artery Disease, New England Journal of Medicine 352(16) (2005) 1685-1695.

[96] G.K. Hansson, Inflammation, atherosclerosis, and coronary artery disease, N Engl J Med 352(16) (2005) 1685-95.

[97] P.C. Calder, Fatty acids and inflammation: the cutting edge between food and pharma, Eur J Pharmacol 668 Suppl 1 (2011) S50-8.

[98] P.C. Calder, Long chain fatty acids and gene expression in inflammation and immunity, Curr Opin Clin Nutr Metab Care 16(4) (2013) 425-33.

[99] R. Wall, R.P. Ross, G.F. Fitzgerald, C. Stanton, Fatty acids from fish: the anti-inflammatory potential of long-chain omega-3 fatty acids, Nutr Rev 68(5) (2010) 280-9.

[100] M. Viladomiu, R. Hontecillas, J. Bassaganya-Riera, Modulation of inflammation and immunity by dietary conjugated linoleic acid, European journal of pharmacology (2015).

[101] S.K. Gebauer, F. Destaillats, F. Dionisi, R.M. Krauss, D.J. Baer, Vaccenic acid and trans fatty acid isomers from partially hydrogenated oil both adversely affect LDL cholesterol: a double-blind, randomized controlled trial, The American journal of clinical nutrition 102(6) (2015) 1339-46. [102] B.M. Nielsen, M.M. Nielsen, M.U. Jakobsen, C.J. Nielsen, C. Holst, T.M. Larsen, N.T. Bendsen, A. Bysted, T. Leth, D.M. Hougaard, K. Skogstrand, A. Astrup, T.I. Sorensen, T. Jess, A cross-sectional study on trans-fatty acids and risk markers of $\mathrm{CHD}$ among middle-aged men representing a broad range of BMI, Br J Nutr 106(8) (2011) 1245-52.

[103] M.S. Da Silva, P. Julien, L. Perusse, M.C. Vohl, I. Rudkowska, Natural Rumen-Derived trans Fatty Acids Are Associated with Metabolic Markers of Cardiac Health, Lipids 50(9) (2015) 873-82.

[104] M. Mazidi, H.K. Gao, A.P. Kengne, Inflammatory Markers Are Positively Associated with Serum trans-Fatty Acids in an Adult American Population, Journal of nutrition and metabolism 2017 (2017) 3848201.

[105] N.T. Bendsen, S. Stender, P.B. Szecsi, S.B. Pedersen, S. Basu, L.I. Hellgren, J.W. Newman, T.M. Larsen, S.B. Haugaard, A. Astrup, Effect of industrially produced trans fat on markers of systemic inflammation: evidence from a randomized trial in women, J Lipid Res 52(10) (2011) 1821-8.

[106] L.A. Penedo, J.C. Nunes, M.A. Gama, P.E. Leite, T.F. Quirico-Santos, A.G. Torres, Intake of butter naturally enriched with cis9,trans11 conjugated linoleic acid reduces systemic inflammatory mediators in healthy young adults, J Nutr Biochem 24(12) (2013) 2144-51.

[107] T. Tholstrup, M. Raff, E.M. Straarup, P. Lund, S. Basu, J.M. Bruun, An oil mixture with trans-10, cis-12 conjugated linoleic acid increases markers of inflammation and in vivo lipid peroxidation compared with cis-9, trans-11 conjugated linoleic acid in postmenopausal women, J Nutr 138(8) (2008) 1445-51. 
[108] U. Riserus, S. Basu, S. Jovinge, G.N. Fredrikson, J. Arnlov, B. Vessby, Supplementation with conjugated linoleic acid causes isomer-dependent oxidative stress and elevated C-reactive protein: a potential link to fatty acid-induced insulin resistance, Circulation 106(15) (2002) 1925-9.

[109] S.E. Steck, A.M. Chalecki, P. Miller, J. Conway, G.L. Austin, J.W. Hardin, C.D. Albright, P. Thuillier, Conjugated linoleic acid supplementation for twelve weeks increases lean body mass in obese humans, J Nutr 137(5) (2007) 1188-93.

[110] A. Smedman, S. Basu, S. Jovinge, G.N. Fredrikson, B. Vessby, Conjugated linoleic acid increased C-reactive protein in human subjects, Br J Nutr 94(5) (2005) 791-5.

[111] M. Raff, T. Tholstrup, S. Basu, P. Nonboe, M.T. Sorensen, E.M. Straarup, A diet rich in conjugated linoleic acid and butter increases lipid peroxidation but does not affect atherosclerotic, inflammatory, or diabetic risk markers in healthy young men, J Nutr 138(3) (2008) 509-14.

[112] L.A. Smit, M.B. Katan, A.J. Wanders, S. Basu, I.A. Brouwer, A high intake of trans fatty acids has little effect on markers of inflammation and oxidative stress in humans, J Nutr 141(9) (2011) 1673-8. [113] T. Radtke, A. Schmid, A. Trepp, F. Dahler, M. Coslovsky, P. Eser, M. Wilhelm, H. Saner, Shortterm effects of trans fatty acids from ruminant and industrial sources on surrogate markers of cardiovascular risk in healthy men and women: A randomized, controlled, double-blind trial, European journal of preventive cardiology 24(5) (2017) 534-543.

[114] M.M. Jacome-Sosa, F. Borthwick, R. Mangat, R. Uwiera, M.J. Reaney, J. Shen, A.D. Quiroga, R.L. Jacobs, R. Lehner, S.D. Proctor, R.C. Nelson, Diets enriched in trans-11 vaccenic acid alleviate ectopic lipid accumulation in a rat model of NAFLD and metabolic syndrome, J Nutr Biochem 25(7) (2014) 692-701.

[115] M.R. Ruth, Y. Wang, H.M. Yu, S. Goruk, M.J. Reaney, S.D. Proctor, D.F. Vine, C.J. Field, Vaccenic and elaidic acid modify plasma and splenocyte membrane phospholipids and mitogen-stimulated cytokine production in obese insulin resistant JCR: LA-cp rats, Nutrients 2(2) (2010) 181-97.

[116] T. Wang, J.N. Lim, J.S. Lee, S.B. Lee, J.H. Hwang, U.S. Jung, M.J. Kim, D.Y. Hwang, S.R. Lee, S.G. Roh, H.G. Lee, Effects of dietary trans- 9 octadecenoic acid, trans- 11 vaccenic acid and cis-9, trans-11 conjugated linoleic acid in mice, Molecular medicine reports 12(2) (2015) 3200-6.

[117] R. Longhi, R.F. Almeida, L. Machado, M.M. Duarte, D.G. Souza, P. Machado, A.M. de Assis, A. Quincozes-Santos, D.O. Souza, Effect of a trans fatty acid-enriched diet on biochemical and inflammatory parameters in Wistar rats, Eur J Nutr 56(3) (2017) 1003-1016.

[118] Y.P. Rao, B.R. Lokesh, Down-regulation of NF-kappaB expression by n-3 fatty acid-rich linseed oil is modulated by PPARgamma activation, eicosanoid cascade and secretion of cytokines by macrophages in rats fed partially hydrogenated vegetable fat, Eur J Nutr 56(3) (2017) 1135-1147. [119] R.A. Siddiqui, K.A. Harvey, N. Ruzmetov, S.J. Miller, G.P. Zaloga, n-3 fatty acids prevent whereas trans-fatty acids induce vascular inflammation and sudden cardiac death, Br J Nutr 102(12) (2009) 1811-9.

[120] H. Poirier, J.S. Shapiro, R.J. Kim, M.A. Lazar, Nutritional supplementation with trans-10, cis-12conjugated linoleic acid induces inflammation of white adipose tissue, Diabetes 55(6) (2006) 163441.

[121] W. Shen, C.C. Chuang, K. Martinez, T. Reid, J.M. Brown, L. Xi, L. Hixson, R. Hopkins, J. Starnes, M. McIntosh, Conjugated linoleic acid reduces adiposity and increases markers of browning and inflammation in white adipose tissue of mice, J Lipid Res 54(4) (2013) 909-22.

[122] D.E. Butz, G. Li, S.M. Huebner, M.E. Cook, A mechanistic approach to understanding conjugated linoleic acid's role in inflammation using murine models of rheumatoid arthritis, American journal of physiology. Regulatory, integrative and comparative physiology 293(2) (2007) R669-76.

[123] S.M. Huebner, J.P. Campbell, D.E. Butz, T.G. Fulmer, A. Gendron-Fitzpatrick, M.E. Cook, Individual isomers of conjugated linoleic acid reduce inflammation associated with established collagen-induced arthritis in DBA/1 mice, J Nutr 140(8) (2010) 1454-61. 
[124] J.A. Muhlenbeck, D.E. Butz, J.M. Olson, D. Uribe-Cano, M.E. Cook, Dietary Conjugated Linoleic Acid-c9t11 Prevents Collagen-Induced Arthritis, Whereas Conjugated Linoleic Acid-t10c12 Increases Arthritic Severity, Lipids 52(4) (2017) 303-314.

[125] A. Jaudszus, M. Krokowski, P. Mockel, Y. Darcan, A. Avagyan, P. Matricardi, G. Jahreis, E. Hamelmann, Cis-9,trans-11-conjugated linoleic acid inhibits allergic sensitization and airway inflammation via a PPARgamma-related mechanism in mice, J Nutr 138(7) (2008) 1336-42.

[126] N.P. Evans, S.A. Misyak, E.M. Schmelz, A.J. Guri, R. Hontecillas, J. Bassaganya-Riera, Conjugated linoleic acid ameliorates inflammation-induced colorectal cancer in mice through activation of PPARgamma, J Nutr 140(3) (2010) 515-21.

[127] C.M. Reynolds, E. Draper, B. Keogh, A. Rahman, A.P. Moloney, K.H. Mills, C.E. Loscher, H.M. Roche, A conjugated linoleic acid-enriched beef diet attenuates lipopolysaccharide-induced inflammation in mice in part through PPARgamma-mediated suppression of toll-like receptor $4, \mathrm{~J}$ Nutr 139(12) (2009) 2351-7.

[128] N.G. Iwata, M. Pham, N.O. Rizzo, A.M. Cheng, E. Maloney, F. Kim, Trans fatty acids induce vascular inflammation and reduce vascular nitric oxide production in endothelial cells, PLoS One 6(12) (2011) e29600.

[129] K.A. Harvey, C.L. Walker, Z. Xu, P. Whitley, R.A. Siddiqui, Trans fatty acids: induction of a proinflammatory phenotype in endothelial cells, Lipids 47(7) (2012) 647-57.

[130] D. Bryk, D. Zapolska-Downar, M. Malecki, K. Hajdukiewicz, D. Sitkiewicz, Trans fatty acids induce a proinflammatory response in endothelial cells through ROS-dependent nuclear factorkappaB activation, J Physiol Pharmacol 62(2) (2011) 229-38.

[131] Y. Pan, B. Liu, Z. Deng, Y. Fan, J. Li, H. Li, Lipid Rafts Promote trans Fatty Acid-Induced Inflammation in Human Umbilical Vein Endothelial Cells, Lipids 52(1) (2017) 27-35.

[132] K.M. Livingstone, D.I. Givens, K.G. Jackson, J.A. Lovegrove, Comparative effect of dairy fatty acids on cell adhesion molecules, nitric oxide and relative gene expression in healthy and diabetic human aortic endothelial cells, Atherosclerosis 234(1) (2014) 65-72.

[133] M.S. Da Silva, J.F. Bilodeau, J. Larose, K. Greffard, P. Julien, O. Barbier, I. Rudkowska, Modulation of the biomarkers of inflammation and oxidative stress by ruminant trans fatty acids and dairy proteins in vascular endothelial cells (HUVEC), Prostaglandins Leukot Essent Fatty Acids 126 (2017) 64-71.

[134] M.S. Da Silva, P. Julien, J.F. Bilodeau, O. Barbier, I. Rudkowska, Trans Fatty Acids Suppress TNFalpha-Induced Inflammatory Gene Expression in Endothelial (HUVEC) and Hepatocellular Carcinoma (HepG2) Cells, Lipids 52(4) (2017) 315-325.

[135] A. Soto-Vaca, J.N. Losso, K. McDonough, J.W. Finley, Differential effect of 14 free fatty acids in the expression of inflammation markers on human arterial coronary cells, Journal of agricultural and food chemistry 61(42) (2013) 10074-9.

[136] A.A. Sneddon, E. McLeod, K.W. Wahle, J.R. Arthur, Cytokine-induced monocyte adhesion to endothelial cells involves platelet-activating factor: suppression by conjugated linoleic acid, Biochim Biophys Acta 1761(7) (2006) 793-801.

[137] M. Goua, S. Mulgrew, J. Frank, D. Rees, A.A. Sneddon, K.W. Wahle, Regulation of adhesion molecule expression in human endothelial and smooth muscle cells by omega-3 fatty acids and conjugated linoleic acids: involvement of the transcription factor NF-kappaB?, Prostaglandins Leukot Essent Fatty Acids 78(1) (2008) 33-43.

[138] E. Stachowska, A. Siennicka, M. Baśkiewcz-Hałasa, J. Bober, B. Machalinski, D. Chlubek, Conjugated linoleic acid isomers may diminish human macrophages adhesion to endothelial surface, International Journal of Food Sciences and Nutrition 63(1) (2012) 30-35.

[139] R.P. Mensink, M.B. Katan, Effect of dietary trans fatty acids on high-density and low-density lipoprotein cholesterol levels in healthy subjects, N Engl J Med 323(7) (1990) 439-45.

[140] J. Li, H. Rao, Q. Bin, Y.-W. Fan, H.-Y. Li, Z.-Y. Deng, Linolelaidic acid induces apoptosis, cell cycle arrest and inflammation stronger than elaidic acid in human umbilical vein endothelial cells through lipid rafts, European Journal of Lipid Science and Technology 119(7) (2017) 1600374. 
[141] S. Tricon, G.C. Burdge, S. Kew, T. Banerjee, J.J. Russell, R.F. Grimble, C.M. Williams, P.C. Calder, P. Yaqoob, Effects of cis-9,trans-11 and trans-10,cis-12 conjugated linoleic acid on immune cell function in healthy humans, Am J Clin Nutr 80(6) (2004) 1626-33.

[142] S. Tricon, G.C. Burdge, S. Kew, T. Banerjee, J.J. Russell, E.L. Jones, R.F. Grimble, C.M. Williams, P. Yaqoob, P.C. Calder, Opposing effects of cis-9,trans-11 and trans-10,cis-12 conjugated linoleic acid on blood lipids in healthy humans, Am J Clin Nutr 80(3) (2004) 614-20. 
Figure 1: Concentrations ( $\mu \mathrm{mol} / \mathrm{L}$ ) of selected 18-carbon TFAs (TVA, EA, CLA9,11 and CLA10,12) in plasma by year in young Canadian adults. Data taken from [55] with permission.

Figure 2. Relationship between adipose tissue CLA9,11 and dietary intake of CLA9,11. Figure shows median values and $95 \%$ Cls for adipose tissue CLA9,11 by deciles of dietary CLA9,11 ( $n=1813$; $p$ for trend 0.0001). Figure taken from Smit, Baylin and Campos, Conjugated linoleic acid in adipose tissue and risk of myocardial infarction, American Journal of Clinical Nutrition, 2010, 92, 34-40 by permission from Oxford University Press and the American Society of Nutrition.

Figure 3. Relationship between experimentally increased intake of CLA9,11 and CLA10,12 in healthy males and the percentage of CLA9,11 and CLA10,12, respectively, in a) plasma phosphatidylcholine; b) plasma cholesteryl esters; c) blood mononuclear cells; d) erythrocytes. Data for a), b) and c) are from Burdge et al. 2004 [58] and data for d) are from Burdge et al. 2005 [60]. Healthy males consumed capsules providing either $80-85 \%$ CLA9,11 (closed squares) or 80-85\% CLA10,12 (closed circles) for 8 weeks.

Figure 4. Summary of the proposed mechanisms by which TFAS affect inflammation. 
Table 1: Structures of the TFAs that are mainly discussed in this review

\begin{tabular}{|l|l|l|}
\hline \multicolumn{1}{|c|}{ TFA } & Systematic Name \\
\hline $\begin{array}{l}\text { trans vaccenic acid; } \\
\text { trans-11 18:1; TVA }\end{array}$ & $\begin{array}{l}\text { trans-11- } \\
\text { octadecenoic } \\
\text { acid }\end{array}$ \\
\hline $\begin{array}{l}\text { Elaidic acid; trans } 9 \\
\text { 18:1; EA }\end{array}$ & $\begin{array}{l}\text { trans-9- } \\
\text { octadecenoic } \\
\text { acid }\end{array}$ \\
\hline $\begin{array}{l}\text { Rumenic acid; cis 9, } \\
\text { trans 11 conjugated } \\
\text { linoleic acid; CLA9,11 }\end{array}$ & $\begin{array}{l}\text { 9Z,11E-octadeca- } \\
\text { 9,11-dienoic acid }\end{array}$ \\
\hline $\begin{array}{l}\text { trans 10, cis 12 } \\
\text { conjugated linoleic } \\
\text { acid; CLA10,12 }\end{array}$ & $\begin{array}{l}\text { 10E,12Z- } \\
\text { octadeca-10,12- } \\
\text { dienoic acid }\end{array}$ \\
\hline $\begin{array}{l}\text { Linoelaidic acid } \\
\text { 9E,12E- } \\
\text { actadecadienoic }\end{array}$
\end{tabular}


Table 2: Selection of reported 18-carbon TFA concentrations in human plasma

\begin{tabular}{|c|c|c|c|}
\hline TFA & $\begin{array}{c}\text { Concentration } \\
(\mu \mathrm{mol} / \mathrm{L}) \\
(\text { mean }+\mathrm{SD})\end{array}$ & Subjects, sample and methods & Reference \\
\hline EA & $16.5 \pm 11.3$ & \multirow{4}{*}{$\begin{array}{l}826 \text { healthy young Canadian males and females } \\
\text { ethno-culturally diverse (Caucasian, East Asian and } \\
\text { South Asian Canadians) } \\
\text { Age : } 22.6 \pm 2.5 \mathrm{y} \\
\mathrm{BMI}: 22.8 \pm 3.4 \mathrm{~kg} / \mathrm{m}^{2} \\
61 \mathrm{FAs}(\mathrm{C} 14-\mathrm{C} 24 \text { ) measured in plasma total lipids } \\
\text { by gas chromatography (fasting blood samples) }\end{array}$} & \multirow[t]{4}{*}{ [69] } \\
\hline TVA & $14.0 \pm 8.1$ & & \\
\hline CLA9,11 & $14.4 \pm 6.2$ & & \\
\hline CLA10,12 & $4.3 \pm 2.5$ & & \\
\hline EA & $32.5 \pm 22.1$ & \multirow{4}{*}{$\begin{array}{l}1294 \text { healthy young Canadian males and females, } \\
\text { part of the cross-sectional Toronto Nutrigenomics } \\
\text { and Health Study, recruited between } \\
\text { September } 2004 \text { and November } 2010 \text {. } \\
\text { Age: } 22.7 \pm 2.5 \text { y } \\
\text { BMI: } 22.9 \pm 3.5 \mathrm{~kg} / \mathrm{m}^{2} \\
\text { TFAs measured in plasma total lipids by gas } \\
\text { chromatography (fasting blood samples) } \\
\text { *Values shown correspond to } 2010 \text { cohort }(n=197)\end{array}$} & \multirow[t]{4}{*}{ [55] } \\
\hline TVA & $9.41 \pm 6.14$ & & \\
\hline CLA9,11 & $17.5 \pm 9.9$ & & \\
\hline CLA10,12 & $6.3 \pm 4.3$ & & \\
\hline EA & $33.4^{\mathrm{a}} \rightarrow 13.5^{\mathrm{b}}$ & \multirow{2}{*}{$\begin{array}{l}\text { a1999-2000: } 1613 \text { subjects, mean age } 42 \text { y, mean } \\
\text { BMI=26.7 kg/m² } \\
\text { b2009-2010: } 2462 \text { subjects, mean age } 46 \text { y, mean } \\
\text { BMI=27.8 kg/m² } \\
\text { Adult US population, multi ethnic. } \\
4 \text { major TFAs measured (palmitoelaidic, trans- } \\
\text { vaccenic, elaidic and linoeladic) by gas } \\
\text { chromatography coupled with mass spectrometry } \\
\text { (fasting blood samples). }\end{array}$} & \multirow[t]{2}{*}[56]{} \\
\hline TVA & $37.9^{a} \rightarrow 18.2^{b}$ & & \\
\hline
\end{tabular}


Table 3: 18-carbon TFAs reported as average percentage of total FAs in different lipid pools in humans

\begin{tabular}{|c|c|c|c|c|c|c|c|}
\hline Lipid pool & Subjects & Country & EA & TVA & CLA9,11 & CLA10,12 & Reference \\
\hline Plasma & Healthy men and women, mean age $22.7 \mathrm{y}$, mean BMI $22.9 \mathrm{~kg} / \mathrm{m}^{2}$ & Canada & 0.38 & 0.12 & 0.21 & 0.07 & [55](2010 data) \\
\hline $\begin{array}{l}\text { Plasma } \\
\text { phosphatidylcholine }\end{array}$ & $\begin{array}{l}\text { Healthy men, mean age } 31 \text { y, mean BMI } 24.6 \mathrm{~kg} / \mathrm{m}^{2} \\
\text { Healthy men, age } 34-60 \mathrm{y}\end{array}$ & $\begin{array}{l}\text { UK } \\
\text { UK }\end{array}$ & - & $\begin{array}{l}- \\
0.28\end{array}$ & $\begin{array}{l}0.21 \\
0.26\end{array}$ & $\begin{array}{l}0.01 \\
-\end{array}$ & {$[58]$} \\
\hline Plasma triglycerides & Healthy men, age $34-60$ y & UK & - & 0.36 & 0.51 & - & [59] \\
\hline $\begin{array}{l}\text { Plasma cholesteryl } \\
\text { esters }\end{array}$ & $\begin{array}{l}\text { Healthy men, mean age } 31 \text { y, mean BMI } 24.6 \mathrm{~kg} / \mathrm{m}^{2} \\
\text { Healthy men, age } 34-60 \mathrm{y}\end{array}$ & $\begin{array}{l}\text { UK } \\
\text { UK }\end{array}$ & - & - & $\begin{array}{l}0.20 \\
0.24\end{array}$ & $\begin{array}{l}<0.01 \\
-\end{array}$ & $\begin{array}{l}{[58]} \\
{[59]}\end{array}$ \\
\hline $\begin{array}{l}\text { Plasma non- } \\
\text { esterified fatty } \\
\text { acids }\end{array}$ & $\begin{array}{l}\text { Healthy men, mean age } 31 \text { y, mean BMI } 24.6 \mathrm{~kg} / \mathrm{m}^{2} \\
\text { Healthy men, age } 34-60 \mathrm{y}\end{array}$ & $\begin{array}{l}\text { UK } \\
\text { UK }\end{array}$ & - & $-\overline{0}$ & $\begin{array}{l}0.36 \\
0.27\end{array}$ & $\begin{array}{l}0.03 \\
-\end{array}$ & $\begin{array}{l}{[58]} \\
{[59]}\end{array}$ \\
\hline Erythrocytes & $\begin{array}{l}\text { Healthy men, age } 34-60 \mathrm{y} \\
\text { Healthy men and women, mean age } 46.9 \mathrm{y} \text {, mean BMI } 21.8 \mathrm{~kg} / \mathrm{m}^{2}\end{array}$ & $\begin{array}{l}\text { UK } \\
\text { China }\end{array}$ & $\begin{array}{l}- \\
0.21 \\
\end{array}$ & $\begin{array}{l}- \\
0.59 \\
\end{array}$ & $\begin{array}{l}0.11 \\
- \\
\end{array}$ & $\begin{array}{l}0.01 \\
- \\
\end{array}$ & $\begin{array}{l}{[60]} \\
{[61]}\end{array}$ \\
\hline $\begin{array}{l}\text { Blood mononuclear } \\
\text { cells (mixture of } \\
\text { lymphocytes and } \\
\text { monocytes) }\end{array}$ & $\begin{array}{l}\text { Healthy men, mean age } 31 \text { y, mean BMI } 24.6 \mathrm{~kg} / \mathrm{m}^{2} \\
\text { Healthy men, age } 34-60 \mathrm{y}\end{array}$ & $\begin{array}{l}\text { UK } \\
\text { UK }\end{array}$ & - & $\overline{0}-\mathbf{0}$ & $\begin{array}{l}0.08 \\
0.07\end{array}$ & $\begin{array}{l}0.03 \\
-\end{array}$ & $\begin{array}{l}{[58]} \\
{[59]}\end{array}$ \\
\hline Adipose tissue & $\begin{array}{l}\text { Healthy men and women, mean age } 56.3 \text { y, mean BMI } 26.9 \mathrm{~kg} / \mathrm{m}^{2} \\
\text { Healthy men and women, mean age } 58 \mathrm{y} \\
\text { Healthy men and women, mean age } 56 \mathrm{y} \text {, mean BMI } 25 \mathrm{~kg} / \mathrm{m}^{2}\end{array}$ & $\begin{array}{l}\text { Australia } \\
\text { Costa Rica } \\
\text { Denmark }\end{array}$ & 0.54 & $\begin{array}{l}0.61 \\
- \\
0.26 \\
\end{array}$ & $\begin{array}{l}0.53 \\
0.45 \\
\end{array}$ & - & $\begin{array}{l}\text { [63] (Control group) } \\
\text { [64] (Control group) } \\
\text { [65] }\end{array}$ \\
\hline Breast milk & $\begin{array}{l}\text { Healthy adolescent mothers, age } 15 \text { to } 19 \text { y } \\
\text { Rural mothers, mean age } 29.1 \text { y } \\
\text { Urban mothers, mean age } 29.1 \text { y }\end{array}$ & $\begin{array}{l}\text { Brazil } \\
\text { Nigeria }\end{array}$ & $\begin{array}{l}0.26 \\
0.07 \\
0.14\end{array}$ & $\begin{array}{l}0.27 \\
0.17 \\
0.20\end{array}$ & $\begin{array}{l}0.03 \\
0.09 \\
0.08\end{array}$ & - & $\begin{array}{l}{[67]} \\
{[68]}\end{array}$ \\
\hline
\end{tabular}


Table 4: Epidemiological studies of TFAs and inflammatory markers in humans.

\begin{tabular}{|c|c|c|c|c|}
\hline Subjects & $\begin{array}{l}\text { Measurement of } \\
\text { TFA exposure }\end{array}$ & $\begin{array}{l}\text { Risk factors } \\
\text { association }\end{array}$ & Outcomes assessed & Reference \\
\hline $\begin{array}{l}823 \text { healthy women from the } \\
\text { Nurses' Health Study } \\
\text { I and II }\end{array}$ & $\begin{array}{l}\text { Dietary intake } \\
\text { assessed from } 2 \text { semi- } \\
\text { quantitative FFQs } \\
\text { averaged for each } \\
\text { subject }\end{array}$ & $\begin{array}{l}\text { Blood markers of } \\
\text { systemic } \\
\text { inflammation }\end{array}$ & $\begin{array}{l}\text { TFA intake was positively associated with sTNF-R1 and sTNF-R2. } \\
\text { TFA intake was not associated with IL-6 or CRP overall but was positively } \\
\text { associated with IL-6 and CRP in women with higher body mass index. }\end{array}$ & [85] \\
\hline $\begin{array}{l}86 \text { ambulatory patients with } \\
\text { established heart failure (cross- } \\
\text { sectional from prospective cohort } \\
\text { study) }\end{array}$ & $\begin{array}{l}\text { Red blood cell } \\
\text { membrane TFAs }\end{array}$ & $\begin{array}{l}\text { Blood markers of } \\
\text { systemic } \\
\text { inflammation }\end{array}$ & $\begin{array}{l}\text { TFA levels were positively associated with IL-1, IL-1 receptor antagonist, IL-10, } \\
\text { TNF- } \alpha \text {, sTNF-R1, sTNF-R2, MCP-1 and brain natriuretic peptide. }\end{array}$ & [84] \\
\hline $\begin{array}{l}730 \text { women from the Nurses' } \\
\text { Health Study I cohort, aged } 43-69 \text { y }\end{array}$ & $\begin{array}{l}\text { Dietary intake } \\
\text { assessed from a } \\
\text { validated FFQ in } 1986 \\
\text { and } 1990\end{array}$ & $\begin{array}{l}\text { Blood biomarkers of } \\
\text { Inflammation and } \\
\text { endothelial } \\
\text { dysfunction }\end{array}$ & $\begin{array}{l}\text { CRP levels were } 73 \% \text { higher among those in the highest quintile of total TFA } \\
\text { intake compared with the lowest quintile. IL-6 levels were } 17 \% \text { higher, sTNF-R2 } \\
5 \% \text { higher, sE-selectin } 20 \% \text { higher, sICAM-1 } 10 \% \text { higher, and sVCAM-1 10\% } \\
\text { higher. TFA intake was positively related to plasma concentration of CRP, } \\
\text { sTNFR-2, sE-selectin, sICAM-1, and sVCAM-1 }\end{array}$ & [86] \\
\hline $\begin{array}{l}393 \text { middle-aged men representing } \\
\text { a broad range of } \mathrm{BMI}\end{array}$ & $\begin{array}{l}\text { Dietary intake } \\
\text { estimated } \\
\text { based on } 7 \text { d dietary } \\
\text { records }\end{array}$ & $\begin{array}{l}\text { Blood biomarkers of } \\
\text { CHD risk }\end{array}$ & $\begin{array}{l}\text { Intake of total TFAs } 1 \cdot 3 \mathrm{~g} / \mathrm{d} \text {, covering a daily iTFA intake of } 0 \cdot 4 \mathrm{~g}(0 \cdot 0-1 \cdot 0) \text { and } \\
\text { rTFA intake of } 0 \cdot 9 \mathrm{~g}(0 \cdot 4-1 \cdot 8) \text {, showed no significant associations with } \\
\text { abdominal fatness, inflammatory markers (IL-6 and CRP), blood lipids, blood } \\
\text { pressure and insulin homeostasis. }\end{array}$ & {$[102]$} \\
\hline $\begin{array}{l}200 \text { individuals } \\
\text { aged from } 18 \text { to } 55 \text { y, including } 100 \\
\text { obese } \\
\text { and } 100 \text { non-obese }\end{array}$ & $\begin{array}{l}\text { Plasma phospholipid } \\
\text { TFAs }\end{array}$ & $\begin{array}{l}\text { Blood biomarkers of } \\
\text { CHD risk }\end{array}$ & $\begin{array}{l}\text { Higher rTFAs were associated with lower insulin levels and blood pressure and } \\
\text { with higher adiponectin levels, unlike their industrial counterparts which were } \\
\text { associated with higher total cholesterol, TAGs (obese subjects) and glycemia } \\
\text { (non-obese subjects). }\end{array}$ & [103] \\
\hline $\begin{array}{l}5446 \text { participants from the 1999- } \\
2000 \text { cycles of the US National } \\
\text { Health and Nutrition Examination } \\
\text { Surveys (NHANES) }\end{array}$ & $\begin{array}{l}\text { Serum TFAs (free and } \\
\text { esterified): mostly } \\
\text { iTFAs }\end{array}$ & $\begin{array}{l}\text { Blood biomarkers of } \\
\text { systemic } \\
\text { inflammation }\end{array}$ & $\begin{array}{l}\text { After adjustment, mean serum TFAs (palmitelaidic acid, EA, TVA and linolaidic } \\
\text { acid) rose with the increasing quartiles of CRP and fibrinogen. In adjusted linear } \\
\text { regression models, serum TFAs were an independent predictor of plasma CRP } \\
\text { and fibrinogen levels. }\end{array}$ & [104] \\
\hline
\end{tabular}


Table 5: Intervention studies with TFAs in humans reporting markers of inflammation.

\begin{tabular}{|c|c|c|c|c|}
\hline Subjects & FA doses and form & Duration and design & Outcomes & Reference \\
\hline $\begin{array}{l}19 \text { subjects ( } 8 \text { males, } 11 \\
\text { females) over age } 50 \mathrm{y} \\
\text { with moderately } \\
\text { elevated LDL } \\
\text { cholesterol levels }\end{array}$ & $\begin{array}{l}3 \text { diets, } 30 \% \text { of calories as fat, of which two } \\
\text { thirds were provided as soybean oil, } \\
\text { soybean oil-based stick margarine, or } \\
\text { butter (randomized order). }\end{array}$ & $\begin{array}{l}32 \text { days for each diet } \\
\text { (washout of } 2 \text { wk } \\
\text { minimum). Double } \\
\text { blind crossover design }\end{array}$ & $\begin{array}{l}\text { iTFA diet } \uparrow \text { PBMCs production of TNF- } \alpha \text { ( } 58 \% \text { ) and IL-6 (36\%). } \\
\text { No differences in delayed-type hypersensitivity skin test response, } \\
\text { lymphocyte proliferation, or levels of IL-2 and PGE } 2 \text { produced between } \\
\text { diets. }\end{array}$ & [82] \\
\hline $\begin{array}{l}50 \text { healthy adult males } \\
\text { with mean age } 42 y\end{array}$ & $\begin{array}{l}8 \% \text { of fat (total } 39 \% \text { of calories) or fatty } \\
\text { acids was replaced across diets with: } \\
\text { cholesterol, oleic acid, TFAs (trans 18:1 } \\
\text { positional isomers similar to that in the US } \\
\text { food supply), stearic acid (STE), TFAs+STE } \\
\text { ( } 4 \% \text { of energy each), and 12:0-16:0 } \\
\text { saturated fatty acids }\end{array}$ & $\begin{array}{l}6 \text { diets for } 5 \text { wk each for } \\
\text { a total controlled } \\
\text { feeding period of } 30 \mathrm{wk} \\
\text { in a randomized } \\
\text { crossover design }\end{array}$ & $\begin{array}{l}\text { TFA diet } \uparrow \text { plasma CRP, IL- } 6 \text { and sE-selectin (5.6\%) concentrations. } \\
\text { Fibrinogen (4.4\%) concentration increased after consumption of the } \\
\text { TFA+STE diet, but not after TFA diet alone. }\end{array}$ & [81] \\
\hline $\begin{array}{l}49 \text { healthy adult males } \\
\text { mean age } 31 \mathrm{y}\end{array}$ & $\begin{array}{l}\text { Supplementation with } 3 \text { doses of CLA9,11 } \\
(0.59,1.19 \text { and } 2.38 \mathrm{~g} / \text { day) or CLA10,12 } \\
(0.63,1.26,2.52 \mathrm{~g} / \mathrm{d})\end{array}$ & $\begin{array}{l}8 \text { wk periods ( } 6 \text { months } \\
\text { each isomer), followed } \\
\text { by a } 6 \text { wk washout and } \\
\text { crossover. Randomized, } \\
\text { double blind, crossover } \\
\text { design. }\end{array}$ & $\begin{array}{l}\text { CLA isomers did not affect lymphocyte subpopulations. } \\
\text { Monocytes expressing ICAM- } 1 \text { were } \downarrow \text { after supplementation with the } \\
\text { highest dose of both isomers than at baseline. } \\
\text { CLA isomers } \downarrow \text { mitogen-induced T lymphocyte activation in a dose- } \\
\text { dependent manner. } \\
\text { No effects on serum concentrations of CRP and on ex vivo cytokine } \\
\text { production by PBMCs in response to LPS (TNF- } \alpha \text {, IL-10, IL-6, IL-1 } \beta \text { and } \\
\text { IL-8) or in response to concanavalin A (IFN- } \gamma \text {, TNF- } \alpha \text {, IL-10, IL-5, IL-4, IL- } \\
\text { 2). Supplementation had no significant effect on body composition, } \\
\text { plasma insulin concentration, homeostasis model for insulin } \\
\text { resistance, or revised quantitative insulin sensitivity check index. } \\
\text { CLA10,12 } \uparrow \text { LDL:HDL cholesterol and total:HDL } \\
\text { cholesterol, whereas CLA9,11 } \downarrow \text { them. } \\
\text { CLA10,12 } \uparrow \text { plasma TAGs compared to CLA9,11. }\end{array}$ & {$[141,142]$} \\
\hline $\begin{array}{l}42 \text { overweight middle- } \\
\text { aged adults }\end{array}$ & $\begin{array}{l}\text { Yogurt-like dairy product enriched } \\
\text { with } 3 \mathrm{~g} \text { of high oleic acid oil (control } \\
\text { group) or } 3 \mathrm{~g} \text { of CLA9,11 or } 3 \mathrm{~g} \text { of CLA10,12 } \\
\text { instead of the oleic acid. }\end{array}$ & $\begin{array}{l}13 \text { wk. } \\
\text { Placebo-controlled, } \\
\text { double- } \\
\text { blind parallel design }\end{array}$ & $\begin{array}{l}\text { CLA isomers had no effect on ex vivo LPS-stimulated cytokine } \\
\text { production by PBMCs and by whole blood. } \\
\text { Plasma CRP concentrations did not change. }\end{array}$ & [7] \\
\hline 32 middle-aged men. & $\begin{array}{l}\text { Milk, butter, and cheese providing } 0.151 \\
\mathrm{~g} / \mathrm{d} \text { (control) or } 1.421 \mathrm{~g} / \mathrm{d} \text { (modified) } \\
\text { CLA9,11 and } 4.7 \mathrm{~g} / \mathrm{d} \text { of TVA. Incorporation } \\
\text { of both FAs in plasma phospholipids and } \\
\text { peripheral blood mononuclear cells was } \\
\text { assessed [59]. }\end{array}$ & $\begin{array}{l}6 \text { wk of intervention, } 7 \\
\text { wk of washout and } \\
\text { crossover in random } \\
\text { order }\end{array}$ & $\begin{array}{l}\text { Consumption of CLA enriched dairy products did not significantly } \\
\text { affect body weight, inflammatory markers (IL-6, sVCAM-1, sICAM-1, } \\
\text { sE-selectin, or CRP), insulin, glucose, TAGs, or total, LDL, and HDL } \\
\text { cholesterol but resulted in a small increase in the ratio of LDL to HDL } \\
\text { cholesterol. }\end{array}$ & [9] \\
\hline
\end{tabular}




\begin{tabular}{|c|c|c|c|c|}
\hline Subjects & FA doses and form & Duration and design & Outcomes & Reference \\
\hline $\begin{array}{l}75 \text { healthy } \\
\text { postmenopausal } \\
\text { women }\end{array}$ & $\begin{array}{l}\text { Daily supplement of } 5.5 \mathrm{~g} \text { of oil rich in } \\
\text { either CLA mixture }(41.17 \% \text { CLA9,11; } 39.9 \% \\
\text { CLA10,12), an oil rich in CLA9,11, or olive } \\
\text { oil (control). Total daily intake of CLA (all } \\
\text { isomers) was } 4.6 \mathrm{~g} \text { with the mixture and } \\
5.1 \mathrm{~g} \text { with the CLA9,11 oil. }\end{array}$ & $\begin{array}{l}16 \text { wk double-blind, } \\
\text { randomized, parallel } \\
\text { intervention study }\end{array}$ & $\begin{array}{l}\text { The CLA mixture resulted in higher plasma CRP, fibrinogen and PAI-1 } \\
\text { than in the CLA9,11 isomer group. The CLA mixture also caused higher } \\
\text { urine } 8-\text { Iso-PGF }_{2 \alpha} \text { compared to CLA9,11 and olive oil. } \\
\text { Plasma IL- } 6 \text {, sVCAM-1, sICAM-1, MCP-1, and TNF- } \alpha \text { were not different } \\
\text { between the groups. }\end{array}$ & {$[107]$} \\
\hline 38 healthy young men & $\begin{array}{l}\text { Butter enriched with } 5.5 \mathrm{~g} / \mathrm{d} \text { of a CLA oil } \\
(39.4 \% \mathrm{CLA} 9,11 ; 38.5 \% \mathrm{CLA} 10,12) \text { was } \\
\text { incorporated into bread rolls, cake, and } \\
\text { chocolate milk. The CLA group received } 4.6 \\
\mathrm{~g} / \mathrm{d} \text { of total CLA ( } 2.5 \mathrm{~g} \text { CLA } 9,11 \text { and } 2.1 \mathrm{~g} \\
\text { CLA10,12) and the control group received } \\
0.3 \mathrm{~g} / \mathrm{d} \text { of CLA9,11. }\end{array}$ & $\begin{array}{l}5 \text { wk double-blind, } \\
\text { randomized, parallel } \\
\text { intervention study }\end{array}$ & $\begin{array}{l}\text { CLA group had } 83 \% \text { higher concentration of urinary 8-Iso-PGF } 2 \alpha \\
\text { compared to control group. } \\
\text { CLAs had no effect on plasma lipids (total, LDL, HDL, TG), CRP, plasma } \\
\text { factor VII activity, PAI-1, insulin and glucose levels. }\end{array}$ & [111] \\
\hline $\begin{array}{l}10 \text { adults ( } 4 \text { male, } 6 \\
\text { female) }\end{array}$ & $\begin{array}{l}200 \mathrm{~g} / \text { wk of pecorino cheese } \\
(3.28 \% \mathrm{TVA}, 1.56 \% \mathrm{CLA} 9,11)\end{array}$ & $\begin{array}{l}10 \text { wk (intervention, } \\
\text { wash out and placebo), } \\
\text { crossover design }\end{array}$ & $\begin{array}{l}\text { Cheese } \downarrow \text { plasma IL-6, IL-8 and TNF- } \alpha \text { (IL-10, IL-12 and vascular } \\
\text { endothelial growth factor unchanged) }\end{array}$ & [8] \\
\hline $\begin{array}{l}49 \text { healthy overweight } \\
\text { postmenopausal } \\
\text { women }\end{array}$ & $\begin{array}{l}\text { Partially hydrogenated soybean oil } \\
\text { incorporated into two bread rolls ( } 15.7 \\
\text { g/day iTFAs) or control oil without added } \\
\text { TFAs. }\end{array}$ & $16 \mathrm{wk}$ & $\begin{array}{l}\text { iTFA intake } \uparrow \text { baseline-adjusted serum TNF- } \alpha \text { (by } 12 \% \text { ), plasma sTNF- } \\
\text { R1 and } 2 . \\
\text { Serum CRP, IL- } 6 \text { and adiponectin and subcutaneous abdominal } \\
\text { adipose tissue mRNA expression of IL-6, IL-8, TNF- } \alpha \text { and adiponectin } \\
\text { as well as ceramide content were not affected by iTFAs. }\end{array}$ & [105] \\
\hline $\begin{array}{l}61 \text { healthy adults ( } 25 \\
\text { male, } 36 \text { female) aged } \\
\text { between } \\
18 \text { and } 65 \mathrm{y}\end{array}$ & $\begin{array}{l}\text { 7\% of energy provided by oleic acid } \\
\text { (control diet), iTFAs (mainly 18:1 trans), or } \\
\text { CLA (mixture of } 80 \% \text { CLA9,11 and } 20 \% \\
\text { CLA10,12); FAs were incorporated into } \\
\text { margarines and yogurt drinks by enriching } \\
\text { fat-free yogurt with } 50 \mathrm{~g} \text { high oleic } \\
\text { sunflower oil, } 50 \mathrm{~g} \text { partially hydrogenated } \\
\text { vegetable fat, or } 50 \mathrm{~g} \text { CLA-rich oil per L. }\end{array}$ & $\begin{array}{l}3 \text { diets for } 3 w k \text {, in } \\
\text { random order (double } \\
\text { blind, randomised } \\
\text { controlled trial) }\end{array}$ & $\begin{array}{l}\text { iTFA diet caused } 4 \% \text { lower sTNF-R1 concentrations and } 6 \% \text { higher sE- } \\
\text { selectin concentrations compared to control, with no significant effect } \\
\text { on other inflammatory markers (IL-6, CRP, TNF-R2, MCP-1). CLA } \\
\text { mixture did not significantly affect inflammatory markers. The urine } \\
\text { concentration of } 8 \text {-iso- PGF } \text { Fa }_{2 \alpha} \text { was greater after the iTFA and the CLA } \\
\text { diet periods than after the control period. }\end{array}$ & [112] \\
\hline $\begin{array}{l}29 \text { healthy adults aged } \\
22 \text { to } 36 y\end{array}$ & $\begin{array}{l}\text { CLA depletion period of restricted dairy fat } \\
\text { intake (depletion phase; CLA intake was } 5.2 \\
\pm 5.8 \mathrm{mg} / \text { day), followed by consuming } 20 \\
\text { g/day of butter naturally enriched with } \\
\text { CLA9,11 (repletion phase; CLA intake of } \\
1020 \pm 167 \mathrm{mg} / \text { day). }\end{array}$ & $\begin{array}{l}\text { Depletion and CLA } \\
\text { repletion period of 8- } \\
\text { wk each }\end{array}$ & $\begin{array}{l}\text { CLA-enriched butter increased serum levels of IL-10, reduced NFK } \beta \text { in } \\
\text { blood and serum levels of TNF } \alpha, I L-2, I L-8 \text { and inactive } \\
\text { metalloproteinase- } 9 \text {. Reduced activity of metalloproteinases } 2 \text { and } 9 \\
\text { in serum was observed during the CLA-repletion period. } \\
\text { CLA-enriched butter had no effects on body composition, serum levels } \\
\text { of adiponectin, C-reactive protein, and IL-4. }\end{array}$ & [106] \\
\hline
\end{tabular}


Table 6: Studies of 18-carbon TFAs in animal models reporting markers of inflammation

\begin{tabular}{|c|c|c|c|c|}
\hline Animal model & FA used, doses and duration & Measurement of TFAs & Outcome & Reference \\
\hline $\begin{array}{l}\text { Wild-type } \\
\text { C57BI/6J female } \\
\text { mice }\end{array}$ & $\begin{array}{l}\text { Daily gavage was performed with } 0.1 \mathrm{~g} \\
\text { sunflower oil or } 0.1 \mathrm{~g} \text { of a mixture with } \\
0.08 \mathrm{~g} \text { sunflower oil and } 0.02 \mathrm{~g} \text { TAGs } \\
\text { containing } 79 \% \text { CLA10,12 (total CLA } \\
\text { isomers } 90.4 \% \text { [ } 79 \% \mathrm{t} 10, \mathrm{c} 12 ; 7 \% \mathrm{c} 9, \mathrm{t} 11 ; \\
\text { and } 3.1 \% \mathrm{t} / \mathrm{t}] \text { ), oleic acid } 2.5 \% \text {, linoleic acid } \\
0.2 \% \text {, and saturated fatty acids } 6.6 \% \text {. For } 1 \text {, } \\
3 \text { or } 7 \text { days. }\end{array}$ & --- & $\begin{array}{l}\text { Oral administration of CLA10,12 led to } \downarrow \text { in body weight and adipose } \\
\text { tissue mass accompanied by an insulin-resistant state characterized by } \\
\text { hyperinsulinemia, } \uparrow \text { resistin levels and } \downarrow \text { leptin and adiponectin levels } \\
\text { triggered after seven gavages. The gene expression of MCP-1, IL- } 6 \text { and } \\
\text { TNF- } \alpha \uparrow \text { in white adipose tissue, while their serum levels of these } \\
\text { inflammatory mediators did not change. CLA supplementation also } \\
\text { induced SOCS3 and produced a reduction in PPARy gene expression in } \\
\text { WAT. Additionally, Immunohistochemistry revealed marked macrophage } \\
\text { infiltration into adipose tissue. }\end{array}$ & {$[120]$} \\
\hline $\begin{array}{l}\text { Wistar rats: } \\
\text { coronary } \\
\text { ligation model } \\
\text { C57/BL6 mice: } \\
\text { femoral artery } \\
\text { ligation model }\end{array}$ & $\begin{array}{l}\mathrm{n}-3 \text { PUFA diet (mixture of maize and fish } \\
\text { oil), with } 21 \% \text { of fats as n-3 PUFAs. TFA diet } \\
\text { (mixture of maize and primex shortening, } \\
\text { rich in EA and linoelaidic acid) with } 17 \% \text { of } \\
\text { fats as TFAs. Experimental diets for } 6 \\
\text { months in the coronary artery model, and } \\
3 \text { weeks in the femoral artery ligation } \\
\text { model. }\end{array}$ & Plasma (only \%) & $\begin{array}{l}\text { Animals on the TFA diet had a lower survival rate due to sudden cardiac } \\
\text { death and exhibited variable degrees of aortic atherosclerotic lesions. }\end{array}$ & [119] \\
\hline JCR:LA-cp rats & EA and TVA $1 \% \mathrm{w} / \mathrm{w}, 16$ weeks & $\begin{array}{l}\text { Plasma PL. Splenocyte } \\
\text { phosphatidylethanolamine } \\
\text { and phosphatidylcholine. }\end{array}$ & $\begin{array}{l}\text { Obese rats had } \uparrow \text { serum haptoglobin and impaired T-cell stimulated } \\
\text { cytokine responses. TVA and EA improved T-cell stimulated cytokine } \\
\text { production, but only TVA normalized serum haptoglobin. TVA also } \\
\text { normalized T-cell stimulated IL-1 } \beta \text { and IFN- } \gamma \text { production }\end{array}$ & [115] \\
\hline $\begin{array}{l}129 S v \text { male } \\
\text { mice }\end{array}$ & $\begin{array}{l}\text { Linoleic acid (LA) alone, CLA10,12 mixed } \\
\text { with LA (50/50) or CLA10,12 mixed with } \\
\text { CLA9,11 (50/50) in three doses in the diet } \\
\text { (w/w): } 0.06 \% \text { (low), } 0.2 \% \text { (intermediate), } \\
\text { and } 0.6 \% \text { (high), equivalent to } 70,240 \text {, and } \\
700 \mathrm{mg} / \mathrm{kg} \text { body weight. For } 7 \text { weeks. }\end{array}$ & $\begin{array}{l}\text { WAT, liver and muscle } \\
\text { tissue }\end{array}$ & $\begin{array}{l}\text { The intermediate and high doses of both CLA treatments } \downarrow \text { total body } \\
\text { weight gain and total WAT depot weights, compared to control. Higher } \\
\text { dose of CLA caused hepatic steatosis, hepatomegaly and } \uparrow \text { serum levels } \\
\text { of MCP-1. IL- } 6 \text { serum levels were } \uparrow \text { with the intermediate dose of the CLA } \\
\text { isomer mixture. } \\
\text { Intermediate or low doses of CLA10,12 or mixed CLAs } \uparrow \text { mRNA markers } \\
\text { or activators of browning in WAT, together with } \uparrow \text { their protein or activity } \\
\text { levels. } \\
\text { Gene expression of MCP-1, IL- } 6, \text { F4/80, and TNF- } \alpha \text { was } \uparrow \text { in the } \\
\text { intermediate and high dose of CLA10,12 + LA or CLA isomer mixture in } \\
\text { WAT. }\end{array}$ & [121] \\
\hline $\begin{array}{l}\text { JCR:LA-cp rats } \\
\text { (obesity model) }\end{array}$ & TVA $1 \% \mathrm{w} / \mathrm{w}, 8$ weeks & --- & $\begin{array}{l}\downarrow \text { total body fat }(-6 \%) \\
\text { stimulated adipose tissue redistribution [reduced mesenteric fat (-17\%) } \\
\text { while increasing inguinal fat (29\%)] } \\
\downarrow \text { adipocyte size }(-44 \%) \\
\uparrow \text { metabolic rate }(7 \%)\end{array}$ & [114] \\
\hline
\end{tabular}




\begin{tabular}{|c|c|c|c|c|}
\hline Animal model & FA used, doses and duration & Measurement of TFAs & Outcome & Reference \\
\hline & & & $\begin{array}{l}\text { 个 insulin sensitivity [lower HOMA-IR (-59\%)]. } \\
\downarrow \text { non-alcoholic fatty liver disease activity scores (-34\%) } \\
\downarrow \text { hepatic (-27\%) and intestinal (-39\%) TAG secretion relative to control } \\
\text { diet } \\
\text { Upregulation of hepatic ApoA1, SRP1, DGAT2 genes. } \\
\text { Downregulation of intestinal SREBP1, FAS, UCP2 genes. }\end{array}$ & \\
\hline Male mice & $\begin{array}{l}0.5 \mathrm{~g} / 100 \mathrm{~g} \text { of diet of TVA, EA or CLA9,11 } \\
\text { for } 4 \text { weeks }\end{array}$ & --- & $\begin{array}{l}\text { After } 10 \text { days, all FAs used induced a reduction in the body weight. } \\
\text { TVA produced a reduction in LDL cholesterol levels. } \\
\text { CLA9,11 and TVA tended to increase the expression of CYP7 } \alpha 1 \\
\text { CLA9,11 induced higher levels of TNF- } \alpha \text {, while TVA reduce them, } \\
\text { compared to control group. }\end{array}$ & [116] \\
\hline Wistar rats & $\begin{array}{l}\text { Partially hydrogenated soybean oil, } 90 \\
\text { days. TFA content in diets used (g/kg): Low } \\
\text { Lard (0.28), High Lard (1.44), Low PHSO } \\
\text { (34.38) and High PHSO (223.4). }\end{array}$ & --- & $\begin{array}{l}\text { Cerebrospinal parameters: PHSO diets increased LDL antibody, IL-1, IL-6 } \\
\text { and TNF- } \alpha \text {. Animals treated with PHSO diets also showed lower levels of } \\
\text { IL-10. } \\
\text { Serum parameters: animals fed with PHSO diets had higher fasting glucose } \\
\text { and insulin levels (both higher in the low concentration of PHSO). } \\
\text { Additionally, PHSO diets led to higher levels of oxidised LDL } \\
\text { Hepatic parameters: PHSO diet induced alterations in TAG levels (lower), } \\
\text { SOD activities and ratio of SOD/CAT +GPX }\end{array}$ & {$[117]$} \\
\hline Wistar rats & $\begin{array}{l}\text { Groundnut oil (10 wt\%), partially } \\
\text { hydrogenated vegetable fat (PHVF, mainly } \\
\text { EA) (10 wt\%), ALA-rich linseed oil (LSO, } 10 \\
\text { wt\%), PHVF blended with LSO at 2.5, } 5.0 \\
\text { and } 7.5 \text { wt\% levels. For } 60 \text { days. }\end{array}$ & Serum lipids & $\begin{array}{l}\text { Macrophages from rats fed PHVF showed a down-regulated expression of } \\
\text { PPARY and up-regulated expressions of cytosolic phospholipase A2, } \\
\text { cyclooxygenase-2, 5-lipoxygenase and NF-K } \beta \text { p65. Macrophages from rats } \\
\text { fed PHVF secreted higher levels of pro-inflammatory eicosanoids and } \\
\text { cytokines. Macrophages from rats fed PHVF blended with LSO at } \\
\text { incremental amounts showed a significant reduction in the protein } \\
\text { expressions of pro-inflammatory markers in dose-dependent manner. }\end{array}$ & [118] \\
\hline DBA/1 mice & $\begin{array}{l}\text { Corn oil (CO, } 6 \text { wt\%), } 5.75 \% \text { CO plus } 0.25 \% \\
\text { CLA10,12, or } 5.5 \% \text { CO plus } 0.5 \% \text { CLA9,11, } \\
\text { prior to arthritis development ( } 3 \text { weeks } \\
\text { before 1ary immunization and for } 70 \text { days; } \\
\text { or starting at the } 2 \text { ary immunization, for } 35 \\
\text { days) }\end{array}$ & Liver & $\begin{array}{l}\text { CLA10,12: mice fed with CLA10,12 isomer at the } 2 \text { ry immunization showed } \\
\text { a more severe initial inflammatory onset of disease, with a trend toward } \\
\text { increased plasma anti-CII IgG1 antibodies levels } \\
\text { CLA9,11: This CLA isomer decreased arthritis incidence by } 39 \% \text { compared } \\
\text { to control mice. } \\
\text { In mice that did not develop arthritis, there was a significant } 49 \% \\
\text { reduction in anti-CII IgG2a antibody levels in CLA9,11 fed mice compared } \\
\text { to control mice fed corn oil. } \\
\text { CLA9,11 exposure produced increased levels of IL-4 and IL-10 compared to } \\
\text { control mice, independent of arthritis induction. }\end{array}$ & {$[124]$} \\
\hline
\end{tabular}


Table 7: In vitro studies of 18-carbon TFAs and inflammation

\begin{tabular}{|c|c|c|c|}
\hline Cell type & $\begin{array}{l}\text { FA used / Inflammatory } \\
\text { stimulus }\end{array}$ & Outcome & Reference \\
\hline 3T3-L1 adipocytes & $\begin{array}{l}\text { CLA10,12 (50 } \mu \mathrm{M} \text { for } 0,8,16,24 \text {, } \\
48 \text {, and } 168 \mathrm{~h})\end{array}$ & $\begin{array}{l}\text { In 3T3-L1 cells CLA10,12 induced IL-6 gene expression and secretion (NF-K } \beta \\
\text { dependent) and decreased gene expression of PPAR } \gamma \text {, whereas SOCS3 mRNA levels } \\
\text { were } \uparrow \text {, with lower uptake of glucose. Nuclear localization of the p65 subunit of } \\
\text { NF-K } \beta \text { was markedly } \uparrow \text { in the CLA10,12-treated cells. PPARy protein was } \downarrow \text { in the } \\
\text { presence of CLA 10,12. }\end{array}$ & [120] \\
\hline $\begin{array}{l}\text { HUVECs } \\
\text { THP-1 cells } \\
\text { Isolated human } \\
\text { peripheral blood } \\
\text { monocytes }\end{array}$ & $\begin{array}{l}\text { Linoleic acid, CLA9,11, CLA10,12 } \\
\text { CLA mix (50:50), 6, 12.5, } 25 \text { and } 50 \\
\mu \mathrm{M} \text { FA for } 24 \mathrm{~h} \\
\text { TNF- } \alpha(5 \mathrm{ng} / \mathrm{ml}) \text { or IL-1 } \beta(10 \mathrm{U} / \mathrm{ml}) \\
\text { for } 2.5 \text { and } 6 \mathrm{~h}\end{array}$ & $\begin{array}{l}\text { CLA } \downarrow \text { binding of both THP-1 and isolated human peripheral blood monocytes to } \\
\text { HUVECs }(40 \%) \text {, with the CLA10,12 isomer suppressing adhesion dose-dependently. } \\
\text { CLA was shown to inhibit cytokine-induced binding by suppressing PAF production } \\
\text { (IL- } 1 \beta \text {, VCAM- } 1 \text { and ICAM- } 1 \text { levels and pro-inflammatory cytokine expression were } \\
\text { unaffected by CLA) }\end{array}$ & [136] \\
\hline $\begin{array}{l}\text { HUVECs } \\
\text { Primary aortic } \\
\text { vascular smooth } \\
\text { muscle cells (vSMCs) }\end{array}$ & $\begin{array}{l}\text { EPA, DHA and palmitic acid } \\
\text { (PA), Linoleic acid, CLA9,11, CLA10, } \\
12, \text { CLA mix (50:50) } \\
25 \mu \mathrm{M} \text { for } 24 \mathrm{~h} \\
\text { TNF- } \alpha \text { ( } 5 \mathrm{ng} / \mathrm{ml} \text { for either } 6 \mathrm{~h} \text { for } \\
\text { ADM or NF-kB activity or } 5 \mathrm{~min} \text {, for } \\
\text { phosphorylation of IkBa) }\end{array}$ & $\begin{array}{l}\text { HUVECs: CLA10,12 and CLA mix, EPA and DHA } \downarrow \text { ICAM- } 1 \text { expression (15-35\%) at } \\
12.5,25 \text { and/or } 50 \text { uM. } \\
\downarrow \text { VCAM- } 1 \text { expression by } 25 \mu \text { M CLA10,12 and mix; omega-3 PUFA and other } \\
\text { concentrations of CLA and TNF-a-induced E-selectin expression were unaffected. } \\
\downarrow \text { NF-K } \beta \text { activity ( } 29 \% \text { and } 30 \% \text {, HUVECs and vSMCs) by } 25 \mu \mathrm{M} \text { CLA mix } \\
\text { CLA isomers alone induced IkB } \alpha \text { phosphorylation (activation NF-K } \beta \text { pathway) }\end{array}$ & [137] \\
\hline HAECS & $\begin{array}{l}\text { EA, Linoelaidic acid at } \\
50,100 \text { and } 200 \mu \mathrm{M} ; 45 \mathrm{~min}, 6 \text { and } \\
16 \mathrm{~h} .\end{array}$ & $\begin{array}{l}\text { Both TFAs } \uparrow \text { the surface expression of ICAM-1 ( } 100 \mu \mathrm{M}, 3 \text { fold increase) and VCAM- } \\
1 \text { ( } 100 \mu \mathrm{M}, 8 \text { fold increase) in a dose-dependent manner. The expression of both } \\
\text { was increased after } 6 \mathrm{~h} \text { FA exposure measured by RT-PCR. } \\
\text { Adhesion of monocytes and lymphocytes was significantly increased when HAECs } \\
\text { were treated with TFAs. } \\
\text { Treatment of HAECs with both of the TFAs for } 45 \text { min induced } \uparrow \text { phosphorylation of } \\
\text { NF-k } \beta \text { p65. Both TFAs significantly increased the intracellular ROS production in a } \\
\text { dose-dependent manner ( } 100 \mu \mathrm{M} \text { inducing over a } 2 \text {-fold increase). }\end{array}$ & [130] \\
\hline $\begin{array}{l}\text { Isolated human } \\
\text { peripheral blood } \\
\text { monocytes } \\
\text { HUVECs }\end{array}$ & $\begin{array}{l}\text { CLA9,11; CLA10,12; LA } \\
\text { Monocytes: } 100 \mu \mathrm{M} \text { for } 7 \text { days } \\
\text { HUVECs: } 30 \text { min, } 12 \mathrm{~h} \text { or } 24 \mathrm{~h} \\
\text { without or with } 100 \mu \mathrm{M} \text {, } \\
\text { stimulation with ox-LDL ( } 50 \mathrm{mg} / \mathrm{ml} \text { ) } \\
\text { for } 8 \mathrm{~h} \text { before the adhesion assay }\end{array}$ & $\begin{array}{l}\text { Both CLAs } \downarrow \text { the expression of CD49d/CD29 (VLA-4) and CD11b/CD18 (Mac-1) on } \\
\text { macrophages. } \\
\text { Both CLAs } \downarrow \text { the surface expression of VCAM in HUVECs, CLA9,11 by } 31.5 \% \text { and } \\
\text { CLA10,12 by } 23 \% \text {, compared to control cells. } \\
\text { CLA9,11 } \downarrow \text { the surface expression of ICAM-1 in HUVECs by } 52 \% \text { compared to } \\
\text { control cells. } \\
\text { Trend to reduce adhesion of macrophages to HUVECs in the cells cultured with CLAs }\end{array}$ & [138] \\
\hline HAECS & $\begin{array}{l}\text { OA, LA, EA, Linoelaidic, Stearic: } 5 \text {, } \\
25,50 \mu \mathrm{M}, 24 \text { and } 48 \mathrm{~h}\end{array}$ & $\begin{array}{l}\text { EA and linoleaidic } \uparrow \text { expression ICAM-1 } \\
\text { Both iTFAs and stearic acid } \uparrow \text { phosphorylation of NF- } \mathrm{k} \beta \text {. }\end{array}$ & [129] \\
\hline $\begin{array}{l}\text { HCASMCs and } \\
\text { human coronary } \\
\text { endothelial cells }\end{array}$ & $\begin{array}{l}\text { Butyric, lauric, myristic, palmitic, } \\
\text { stearic, oleic, linoleic, linolenic, } \\
\text { arachidonic, EPA, DHA, EA, TVA and }\end{array}$ & $\begin{array}{l}\uparrow I L-6 \text { and MCP-1 levels were observed only in HCASMCs for TVA and EA, } \\
\text { respectively. } \\
\text { Linoleic acid was less pro-inflammatory in both cell lines when compared to CLA. }\end{array}$ & [135] \\
\hline
\end{tabular}




\begin{tabular}{|c|c|c|c|}
\hline Cell type & $\begin{array}{c}\text { FA used / Inflammatory } \\
\text { stimulus }\end{array}$ & Outcome & Reference \\
\hline & $\begin{array}{l}\text { CLA (200 } \mu \mathrm{M}, \text { HCAECs } 8 \mathrm{~h} ; \\
\text { HCASMCs } 20 \mathrm{~h})\end{array}$ & & \\
\hline $\begin{array}{l}\text { HUVECs } \\
\text { HepG2 cells } \\
\text { (hepatocellular } \\
\text { carcinoma) }\end{array}$ & $\begin{array}{l}\text { TVA, EA, trans-palmitoleic } \\
(5-150 \mu \mathrm{M}) \\
\text { Mixture of TVA and trans- } \\
\text { palmitoleic }(150 / 50 \mu \mathrm{M}) \text { TNF- } \alpha \\
(2 \mathrm{ng} / \mathrm{ml}, 24 \mathrm{~h})\end{array}$ & $\begin{array}{l}\text { HUVECs: rTFAs and EA } \downarrow \text { inflammatory gene expression (TNF- } \alpha \text {, VCAM-1 and SOD- } \\
2 \\
\text { HepG2 cells: rTFAs } \downarrow \text { inflammatory gene expression (TNF, IL-8) }\end{array}$ & [134] \\
\hline HUVECS & $\begin{array}{l}\text { OA, EA } \\
(100 \mu \mathrm{M})\end{array}$ & $\begin{array}{l}\text { EA } \uparrow \text { nuclear translocation of NF- } \mathrm{k} \beta \mathrm{p} 65 \text { and phosphorylated ERK1/2; } \uparrow \text { expression } \\
\text { of TLR-4 } \\
\text { Lipid rafts may be involved in TFA induced-inflammation in HUVECs. }\end{array}$ & [131] \\
\hline HUVECS & $\begin{array}{l}\text { TVA, EA, trans-palmitoleic }(50 \mu \mathrm{M}) \\
\text { Mixture of TVA and trans- } \\
\text { palmitoleic } \\
(150 / 50 \mu \mathrm{M})\end{array}$ & $\begin{array}{l}\text { rTFAs } \downarrow \text { PG excretion and inflammatory gene expression (TNF and VCAM-1). } \\
\text { rTFAs and iTFAs } \uparrow \text { different classes of F2-isoP (EA } \uparrow \text { class VI F2-isoP isomers, TVA } \\
\uparrow \text { mostly class III isomers) }\end{array}$ & [133] \\
\hline
\end{tabular}

